\title{
LA DOCTRINA DEL «LEVANTAMIENTO DEL VELO» Y LAS SOCIEDADES INTERPUESTAS ${ }^{1}$
}

\author{
Ricardo de Angel Yágüez \\ Catedrático de Derecho civil de la Universidad de Deusto
}

Sumario: 1. Introducción y propósito de la presente ponencia. 2. La «técnica» del levantamiento del velo. Su recepción por la doctrina española. Dudas acerca de su necesidad. 3. La acogida de esta doctrina en nuestra jurisprudencia. 4. El «levantamiento del velo» como instrumento para extender la responsabilidad. A) Sentencias que lo hacen. B) Sentencias que lo rechazan y advierten de la cautela necesaria en esta materia.

\section{Introducción y propósito de la presente ponencia}

1. Uno de los autores que con más lucidez se ha manifestado en torno a la persona jurídica, y en concreto a las por él llamadas sus «funciones y disfunciones», Capilla Roncero, ha escrito recientemente las siguientes palabras: «Uno de los principales problemas suscitados por las personas jurídicas es la posibilidad de que se produzca el denominado "abuso de la personalidad jurídica". Nuestra jurisprudencia ha acogido, con entusiasmo, la llamada "técnica del levantamiento del velo" para poner coto a los actos abusivos. Pero su utilización indiferenciada exige que se precisen con mayor rigor las condiciones y límites de la aplicación de esa técnica» (voz «Persona jurídica» en Enciclopedia Jurídica Básica, Madrid, 1995, III, p. 4.864).

Esta breve pero luminosa reflexión constituye la mejor justificación objetiva del propósito que ha guiado a los organizadores de este ciclo al incluir en el mismo el sugestivo tema que nos reúne.

1 Se trata del texto de la ponencia presentada por el autor en el ciclo del Plan territorial de formación de Cantabria para Jueces y Magistrados. Consejo General del Poder Judicial y Tribunal Superior de Justicia de Cantabria. Santander, 16 de noviembre de 1995. 
En efecto, no ya uno de los principales problemas que plantea la persona jurídica, sino probablemente el más importante (dejando de lado las cuestiones dogmáticas acerca de su naturaleza jurídica, por cierto de más significado práctico que lo que a primera vista pudiera parecer), es el consistente en la contemplación de aquellos casos en que se produce el denunciado «abuso» de la persona jurídica, esto es, la utilización de esta figura para fines distintos de los que constituyen su razón de ser.

No es menos cierto, en segundo lugar, que nuestra jurisprudencia ha acogido con verdadero entusiasmo (esta palabra de Capilla Roncero me parece muy afortunada) la técnica consistente en levantar el velo de la persona jurídica y, penetrando en su interioridad, descubrir la real naturaleza de los intereses individuales que bajo ella existen (a veces, nunca mejor dicho, se ocultan).

No hay más que echar una ojeada a los repertorios jurisprudenciales para comprobar cómo a partir de la sentencia de la Sala Primera de 28 de mayo de 1984, sobre todo, abundantes resoluciones de los diferentes órdenes jurisdiccionales invocan aquella técnica (bien para acogerla, bien para desecharla), con el objetivo de dar solución a muy variados conflictos de la vida real.

Hasta tal punto es así, que no parece exagerado afirmar que la doctrina del levantamiento del velo, valga la expresión un tanto frívola, «está de moda». Lo está en el plano doctrinal, como se desprende de las referencias bibliográficas de los últimos diez años, y lo está también en el terreno que podríamos llamar «práctico»; sobre todo, en el de los abogados, pendientes del último pronunciamiento jurisprudencial (más si es civil o laboral) para dar una determinada orientación a sus demandas o a sus oposiciones a ellas.

Por último, es también evidente que —como pone de manifiesto Capilla Roncero- se muestra cada día con más justificación la necesidad de definir las condiciones y límites en la aplicación de la técnica del levantamiento del velo; y esto, para no hacer de ella un instrumento que dé cabida a toda pretensión en la que la existencia de una persona jurídica sea, simplemente, «molesta» o «incómoda» para los intereses de una de las partes en conflicto.

2. Pero si la justificación objetiva de la presente ponencia resulta incuestionable, más que dudosa es la, por así decirlo, subjetiva, esto es, la que ha dado lugar a que sea precisamente yo quien me dirija a ustedes hablando de esta cuestión.

Doy por seguro que si alguna explicación tuviera mi participación en este ciclo, esa explicación no es otra que la de ser autor de un libro cuya tercera edición ve ahora la luz. Se trata de la obra La doctrina del «levantamiento del velo» de la persona jurídica en la jurisprudencia, Madrid, 1995. 
Pero no por falsa modestia, sino por elemental realismo, me apresuro a señalar que ese libro no tiene otro mérito que el de la jurisprudencia que recoge. En efecto, mi propósito no ha sido sino el de elegir los pronunciamientos jurisprudenciales de mayor interés en relación con la materia que nos ocupa, inicialmente en los ámbitos civil y social; luego en el terreno contencioso-administrativo (segunda edición); y por fin en el orden jurisdiccional penal, en el que la interesante sentencia de la $\mathrm{Au}-$ diencia Provincial de Barcelona de 5 de abril de 1994 brinda un curioso ejemplo de expresa invocación del levantamiento del velo en el Derecho criminal (tercera edición). Hecho ese acopio jurisprudencial, que en las sucesivas ediciones se ha ido poniendo al día, mi segundo objetivo ha sido el de ordenar las resoluciones de acuerdo con un criterio de sistematización que, entre los posibles, me parece razonable: el de agrupar las sentencias en función de lo que, según el pensamiento de los diversos órganos judiciales, fue en cada caso el fin perseguido al formarse una persona jurídica, casi siempre una sociedad mercantil; o incluso en función de lo que, también en la opinión del correspondiente Tribunal, constituyó el resultado de la existencia (entre los litigantes o de forma próxima a ellos) de una persona jurídica.

3. Siendo como es tan amplio el marco de los problemas jurídicos en que puede encontrar aplicación la doctrina que nos ocupa, resulta obligado delimitar el ámbito de mi intervención.

Esta exposición va a versar sobre la llamada «ruptura del hermetismo» de la persona jurídica en lo que atañe a la denominada «comunicación» de la responsabilidad patrimonial, extendiendo la de una persona jurídica a los miembros que la componen. Intentaré poner de relieve los criterios que movieron a los Tribunales a llevar a cabo la indagación de lo que subyacía en el fondo de las personas jurídicas que en cada pleito estaban presentes. Y esto irá precedido de unas consideraciones sobre el origen de la doctrina del levantamiento del velo, sobre su «recepción» por nuestra doctrina y algunas de las dudas dogmáticas que plantea, así como en torno a la acogida que esta «técnica» ha tenido en la jurisprudencia española.

\section{La «técnica» del levantamiento del velo. Su recepción por la doctrina española. Dudas acerca de su necesidad}

1. Una de las formas, a mi juicio la más gráfica, de describir lo que es el levantamiento del velo de la persona jurídica, consiste en la traducción literal de la expresión inglesa disregard of legal entity. En efecto, levantar el velo es «desentenderse de la personalidad jurídica»; o dicho 
de otro modo, prescindir de la forma externa de la persona jurídica, como si ésta no existiese, para a partir de ahí penetrar en su interioridad y adentrarse en su seno (su substratum, como suelen decir nuestra doctrina y nuestra jurisprudencia). Todo ello, para así poner coto a los fraudes y abusos que por medio del «manto protector» de la persona jurídica se pueden cometer.

En virtud de ese «descorrer el velo», si los Tribunales entienden que la estructura formal de la persona jurídica se utiliza con una finalidad fraudulenta y de forma desajustada respecto a lo que constituye su justificación, aquéllos descartan o prescinden de esa persona jurídica o de alguna de las consecuencias que de ella dimanan, como es la de la separación absoluta entre la persona social y cada uno de sus miembros, con la correlativa separación entre sus respectivos patrimonios. De esta forma, mediante la denominada «ruptura del hermetismo de la persona jurídica» se prescinde por los jueces de las consecuencias que en circunstancias normales desencadenaría dicha figura; lo que es tanto como prescindir de ella misma, si bien a los efectos limitados de lo que en cada caso se encuentre en juego.

2. El «desentenderse» de la persona jurídica no es siempre, ni necesariamente, obra de la jurisprudencia. Hay ocasiones en que esa operación intelectual se lleva a cabo por la propia ley. Ocurre esto, por ejemplo, con la denominada «sociedad de un solo socio», puesto que el artículo 128 de la Ley de sociedades de responsabilidad limitada de 23 de marzo de 1995 (y por extensión la Ley de sociedades anónimas, en su artículo 311) establece un régimen de responsabilidad distinto del general cuando ha habido contratos entre el socio único y la sociedad unipersonal sin someterse a los requisitos de publicidad al efecto establecidos. Me ocuparé más adelante de esta nueva configuración de la sociedad unipersonal en nuestro ordenamiento.

Pero cuando hablamos del levantamiento del velo de la persona jurídica solemos referirnos a un criterio judicial, esto es, a una forma de reflexión o de razonamiento por cuya virtud los jueces prescinden de la cobertura formal que dicha institución significa, con el propósito de impedir que su inadecuada utilización conduzca a soluciones contrarias (o al menos distintas) de las que se alcanzarían con el correcto uso de la figura. Por decirlo de otro modo, se asigna a esta doctrina el carácter de «creación jurisprudencial». No es casual que muy frecuentemente se diga de ella que es una «técnica» en manos de los jueces.

Siempre se cita como antecedente un caso de la jurisprudencia inglesa, el conocido como Salomon v. Salomon and Company Limited. Y lo curioso es que en este juicio no prosperó el levantamiento del velo que pretendió el liquidador de la sociedad. Aron Salomon, que se había dedi- 
cado durante algunos años al negocio de pieles, decidió constituir una sociedad que adquiriese su negocio, formada por él mismo y seis miembros de su familia, ostentando estos últimos sólo una acción cada uno. El se reservó las restantes hasta un total de 20.000 acciones. Después de que Salomon y dos de sus hijos fueran nombrados administradores, se firmó el contrato para la venta del negocio a la sociedad. Salomon, en cuanto tal administrador, constituyó en favor de sí mismo unas obligaciones privilegiadas en garantía del pago de parte del precio de esta venta; en otras palabras, constituyó una deuda de la sociedad frente a él, preferente a los demás créditos. El negocio no prosperó y cuando la sociedad fue liquidada, un año después, su pasivo era superior a su activo. Salomon hizo valer su condición de acreedor privilegiado para cobrar, absorbiendo todos los bienes de la sociedad en perjuicio de los restantes acreedores. El liquidador, que representaba a los acreedores no privilegiados de la sociedad, adujo que el negocio era, en realidad y todavía, el negocio del propio Aron Salomon, y que la sociedad no era sino una ficción destinada a limitar la responsabilidad por deudas de Salomon contraídas en el ejercicio de su actividad empresarial. De aceptarse esta tesis, Salomon tendría que ser obligado a satisfacer las deudas de la sociedad y su crédito por las obligaciones suscritas debía ser pospuesto hasta que los restantes acreedores de la sociedad fueran satisfechos.

Planteado el caso ante los Tribunales, el Juez Williams se mostró conforme con el criterio del liquidador. Sostuvo que los otorgantes del negocio de constitución de la sociedad distintos de Salomon eran meros testaferros y que el único propósito de Salomon al formarla fue el de usarla como un «agente» que hiciera negocios por él. El Tribunal de Apelación llegó a la misma conclusión, aunque por medio de otro razonamiento. Entendió que las leyes mercantiles intentaban conferir el privilegio de la responsabilidad limitada sólo a los genuinos accionistas independientes que aportaban su capital para comenzar una empresa, y no a un hombre que en realidad era el único propietario del negocio y que sólo se dedicó a encontrar seis testaferros para cumplir con ellos las formalidades de constitución de la sociedad.

No obstante, la Cámara de los Lores, en sentencia de 1897, revocó por unanimidad los fallos del Juez Williams y del Tribunal de Apelación y sostuvo que Salomon no era responsable ni ante la sociedad ni ante los acreedores, que las obligaciones fueron válidamente emitidas y que el derecho de garantía que pesaba sobre el activo de la sociedad era efectivo respecto a ésta y respecto a los acreedores.

A pesar de que se cita este caso - con razón- como precursor en la invocación de unos argumentos tan próximos al disregard of legal entity, ha sido la jurisprudencia norteamericana la que sobre todo ha dado auge 
al levantamiento del velo. No es el caso de entrar en datos bibliográficos y por eso me limito a citar una obra en castellano muy ilustrativa al respecto. Me refiero a la de Dobson, El abuso de la personalidad (en el Derecho privado), 2. ${ }^{\text {a }}$ edición, Buenos Aires, 1991.

El problema de fondo, esto es, el de la utilización abusiva de la persona jurídica, fue concienzudamente analizado en una magnífica obra de Serick, de 1955, que causó un gran impacto en la doctrina europea. Fue publicada en español en 1959 bajo el título Apariencia y realidad en las sociedades mercantiles (traducción de Puig Brutau, Barcelona).

Mientras tanto, en España, De Castro publicó en 1949 («Anuario de Derecho civil», pp. 1.397 ss.) un penetrante trabajo titulado La sociedad anónima y la deformación del concepto de persona jurídica, del que, como he manifestado en alguna otra ocasión, bien puede decirse que hizo época. Siguieron otros estudios del mismo autor, en idéntica línea, hasta el titulado Formación y deformación del concepto de persona jurídica (notas preliminares para el estudio de la persona jurídica), dentro de la obra Centenario de la Ley del Notariado («Estudios jurídicos varios», Sección tercera, vol. I, Madrid, 1964, pp. 85 ss.). Estos y otros materiales posteriores se recogieron, en afortunada iniciativa, en el libro La persona jurídica, Madrid, 1981.

A veces de forma simultánea a la obra del Profesor De Castro, pero sobre todo con posterioridad a ella, vieron y han visto la luz en nuestro país otros trabajos que de manera más o menos directa plantean la cuestión del levantamiento del velo de la persona jurídica. No procede entrar en su detalle ahora.

3. Muchas son las consideraciones que desde el punto de vista dogmático sugiere la doctrina que nos ocupa, pero me limito a mencionar $-\mathrm{y}$ en pocas palabras - las que a mi juicio son más importantes.

En primer lugar, ocioso es señalarlo, el levantamiento del velo de la persona jurídica pone en peligro la razón de ser o justificación misma de la figura. No se puede dudar que la persona jurídica es una construcción lícita y útil; y es innegable, por tanto, que debe mirarse con prevención o al menos con cautela cualquier doctrina o cualquier criterio judicial que puedan ponerla en peligro. No carece de sentido, sino que es muy fundada, la puntualización que se encuentra en muchas de las sentencias de nuestros Tribunales que se inclinan por fórmula del levantamiento del velo. Sobre todo a partir de la sentencia de 28 de mayo de 1984, es habitual que al tratar de justificarse la práctica de penetrar en el substratum personal de entidades y sociedades se diga de ellas que son una «ficción o forma legal», pero para inmediatamente advertir que se trata (la persona jurídica) de una figura «de respeto obligado, por supuesto». 
A nadie se le oculta que el primer motivo de reserva respecto de la doctrina del levantamiento del velo consiste en el peligro de que con ella puedan tambalearse algunos de los objetivos legítimos que la persona jurídica propicia. El jurista práctico se percata fácilmente de la inquietud que en la vida de la empresa y de los negocios han venido a sembrar (aunque acaso de forma un poco desproporcionada) algunos pronunciamientos jurisprudenciales de los que han optado por ese «prescindir» de la persona jurídica de que hablamos. Y no hay que descartar que esos temores hayan venido a producir alguna suerte de disuasión para la puesta en práctica de fórmulas jurídicas que quizá hace 15 ó 20 años no habrían suscitado el más mínimo reparo.

La otra gran cuestión que aquí se plantea es la de la justificación misma de la práctica judicial de «levantar el velo». No faltan opiniones de que esa «técnica» puede tener sentido en un Derecho de creación jurisprudencial, como es el anglosajón, pero no en los ordenamientos jurídicos de tradición romanista.

Dicho de otro modo, no parece impertinente preguntarse si la doctrina del levantamiento del velo no es un exotismo innecesario, habida cuenta que la dogmática jurídica y los ordenamientos positivos europeooccidentales brindan al intérprete, y en concreto al juzgador, conceptos e instrumentos jurídicos bastantes para adoptar soluciones como las que el levantamiento del velo puede ofrecer. Nociones jurídicas básicas como son la de fraude a la ley, o la de fraude de acreedores, o la de abuso del derecho, o la de equidad, o en fin la de buena fe (como canon de comportamiento en el ejercicio de los derechos), se presentan, en efecto, como resortes jurídicos adecuados para solventar muchos de los problemas que, quizá con una excesiva inclinación a «lo nuevo», dicen resolverse mediante el recurso a la técnica del levantamiento del velo.

También en este punto procede advertir cómo nuestra propia jurisprudencia, incluso en los casos en que hace uso de esa técnica, suele justificar la adopción de tan particular doctrina (de la que se recomienda un uso «prudencial», y desde luego «según casos y circunstancias»), advirtiendo que su puesta en práctica es al amparo de la equidad y de la buena fe y para evitar un «ejercicio antisocial» de los derechos derivados de la personalidad y para poner coto al fraude. Parece como si en esas sentencias se estuviera reconociendo que, en el fondo, el levantamiento del velo no es más que una operación mecánica (se explicaría así que se hable de una «técnica»), cuyo fundamento sustantivo se halla en alguna o en todas esas nociones jurídicas antes citadas, en cuanto expresivas de límites o fronteras en la aplicación de las normas jurídicas o en el ejercicio de los derechos subjetivos. 
Entiendo que es ésta la cuestión medular que se plantea cuando hablamos de la doctrina en examen. Y no puedo ocultar que no acabo de ver claras las cosas. Me parece que en la inmensa mayor parte de los casos en que se acude al levantamiento del velo, el Tribunal podía haber llegado al mismo resultado mediante el recurso a alguno o algunos de esos conceptos básicos que he citado. Pero acaso queden fuera de esta apreciación aquellas hipótesis en que, cuando el órgano judicial «levanta el velo» de una persona jurídica, lo hace para poner de manifiesto, no ya que la persona jurídica en cuestión se hubiere constituido de mala fe o con ánimo de defraudar, sino que lo rechazable es poner en práctica, con todas sus consecuencias, alguno o algunos de los principios y mecanismos jurídicos que tienen su asiento en la idea de que la persona jurídica goza de una identidad autónoma y perfectamente diferenciada de la de los miembros que la componen.

En concreto, esta última reflexión viene sugerida, por ejemplo, por la sentencia a la que todos (los jueces y quienes no lo somos) acudimos como más significativa. Me refiero a la ya citada de 28 de mayo de 1984 , cuyos antecedentes de hecho permiten descartar que la constitución de la sociedad EMAYA por parte del Ayuntamiento de Palma de Mallorca estuviera inspirada por el propósito de causar el perjuicio que, de no haberse practicado el levantamiento del velo por la Sala Primera, se habría producido a la demandante de aquel pleito.

\section{La acogida de esta doctrina en nuestra jurisprudencia}

1. Como hemos venido diciendo, el primer pronunciamiento jurisprudencial en que de manera declarada vino a hacerse aplicación de la doctrina del levantamiento del velo fue la de la Sala Primera de 28 de mayo de 1984. Esto no significa que con anterioridad no se hubieran dictado sentencias en las que el Tribunal Supremo «prescindiera de la persona jurídica» para llegar al desenlace de sus correspondientes fallos, según luego tendremos ocasión de comprobar. Lo que ocurre es que éste de 1984 es el primer caso en que no sólo se utilizan expresamente las palabras «levantamiento del velo», sino el primero también en que se formula, por así decirlo, un cuerpo de doctrina en torno a la figura.

La demandante, una sociedad anónima, había sufrido daños en sus instalaciones como consecuencia de inundaciones y humedades resultantes de averías producidas en la red municipal de abastecimiento de agua de Palma de Mallorca. Por ello, entabló demanda contra Empresa Municipal de Aguas y Alcantarillado, S.A. (EMAYA), y contra el Ayuntamiento de la ciudad. 
Se opusieron los demandados y, después de que se acumularan a los autos otros seguidos a instancias de la misma demandante contra una tercera compañía denominada ESA, el Juzgado dictó sentencia desestimatoria de la demanda. La sociedad actora interpuso recurso de apelación, que fue estimado en parte por la Audiencia. EMAYA formuló recurso de casación, que fue desestimado por el Tribunal Supremo, siendo ponente el señor De la Vega Benayas.

La sentencia del Supremo pone de relieve que inicialmente se dirigió la reclamación administrativa contra el Ayuntamiento y luego, para soslayar el problema de la legitimación pasiva, la demanda se planteó contra aquél y la citada empresa municipal. La Audiencia, reconociendo y admitiendo que EMAYA tenía propia y distinta personalidad, independiente de la del Ayuntamiento (por lo que absolvió a éste de la reclamación), condenó a la primera entidad al pago de la indemnización solicitada, a pesar de la excepción que ella había propuesto, esto es, la de haber prescrito el derecho ejercitado en virtud del artículo 1.968 del Código civil. Téngase presente que el acto de conciliación contra EMAYA se hizo transcurrido con creces un año desde el hecho dañoso.

Para adoptar su decisión, la Audiencia se apoyó no sólo en una interpretación restrictiva del instituto de la prescripción, sino en una asimilación de la reclamación previa administrativa a la interpelación extrajudicial como modo de interrupción de la prescripción (artículo $1.973 \mathrm{del}$ Código civil), habida cuenta que dicha reclamación previa se dirigió contra quien, como el Ayuntamiento, no era sino «órgano de la sociedad anónima demandada» y «el Alcalde (era) Presidente de su Consejo de Administración», por tanto representante de aquélla. Habiendo sido el Alcalde «pleno recipiendario de la reclamación», la Audiencia reconoció a tal reclamación la eficacia interruptiva que se postulaba por la demandante, al darse en el receptor la doble condición de Alcalde y Presidente del Consejo de la anónima. Y todo ello, so pena de «quebrantar (de otro modo) los principios de buena fe y de confianza que inspiran todo el tráfico jurídico privado», aquí en la modalidad de gestión de un servicio público equivalente a la gestión directa.

El Tribunal Supremo, como decíamos, declaró no haber lugar al recurso de casación, que invocaba violación del artículo 1.973 del Código civil, pues — se decía - al gozar de personalidad jurídica independiente del Ayuntamiento, EMAYA no podía ser afectada por la interpelación que al Ayuntamiento (no a ella) se había formulado por la actora dentro del plazo hábil para interrumpir la prescripción en curso.

La Sala Primera razona en unos términos que luego han venido a repetirse en muchas otras sentencias (y no sólo del orden jurisdiccional ci- 
vil), circunstancia que hace de esta sentencia un auténtico leading case, por utilizar un término muy expresivo del Derecho inglés. Son éstos:

«Que ya, desde el punto de vista civil y mercantil, la más autorizada doctrina, en el conflicto entre seguridad jurídica y justicia, valores hoy consagrados en la Constitución (artículos 11 y 9.3), se ha decidido prudencialmente, y según casos y circunstancias, por aplicar por vía de equidad, y acogimiento del principio de buena fe (artículo 7.1 del Código civil), la tesis y práctica de penetrar en el "substratum” personal de las entidades o sociedades, a las que la ley confiere personalidad jurídica propia, con el fin de evitar que al socaire de esa ficción o forma legal (de respeto obligado, por supuesto) se puedan perjudicar ya intereses privados o públicos o bien ser utilizada como camino del fraude (artículo 6.4 del Código civil), admitiéndose la posibilidad de que los Jueces puedan penetrar ("levantar el velo jurídico") en el interior de esas personas cuando sea preciso para evitar el abuso de esa independencia (artículo 7.2 del Código civil) en daño ajeno o de "los derechos de los demás" (artículo 10 de la Constitución) o contra intereses de los socios, es decir, de un mal uso de su personalidad, de un "ejercico antisocial" de su derecho (artículo 7.2 del Código civil), lo cual no significa - ya en el supuesto del recurso- que haya de soslayarse o dejarse de lado la personalidad del ente gestor constituido en sociedad anónima sujeta al Derecho privado, sino sólo constatar, a los efectos del tercero de buena fe (la actora y recurrida perjudicada), cuál sea la auténtica y "constitutiva" personalidad social y económica de la misma, el substrato real de su composición personal (o institucional) y negocial, a los efectos de la determinación de su responsabilidad ex contractu o aquiliana, porque, como se ha dicho por la doctrina extranjera, "quien maneja internamente de modo unitario y total un organismo no puede invocar frente a sus acreedores que existen exteriormente varias organizaciones independientes" y menos "cuando el control social efectivo está en manos de una sola persona, sea directamente o a través de los testaferros o de otra sociedad", según la doctrina patria.

Que también en el ámbito del Derecho administrativo, cuando se habla de los "entes públicos" o de gestión ("mutatis mutandis"), a los que se reviste de una forma jurídica perteneciente al Derecho privado (sociedades anónimas, por ejemplo), según se señala por autorizada doctrina, no se hace sino utilizar una técnica ofrecida por ese Derecho de modo instrumental, del uso de un procedimiento en el que la sociedad aparece como una simple forma para encubrir la creación de un ente filial puro y simple, externamente regido por el Derecho privado, pero en realidad - internamente - de la pertenencia de la Administración, tal como en el caso del recurso ocurre y se declara por la sentencia de instancia, en el que, según el contrato, el Ayuntamiento es órgano de la sociedad municipal y el Alcalde su Presidente del Consejo, es decir, con el poder, siquiera compartido, de gestión de la entidad, circunstancia más 
que suficiente para no considerar tercero o extraño al Ayuntamiento con respecto a la sociedad municipal demandada y, consecuentemente, bastante para llegar a la misma conclusión que la sentencia impugnada, es decir, que la interpelación hecha al Municipio vale para la sociedad como órgano integrante de ésta (debe de querer decir "de éste") y que ésta ni puede ni debe pretender escapar de sus efectos, determinados en el artículo 1.973 del Código civil, por consiguiente no violado.»

Como antes decía, y con independencia del mérito «histórico» que esta sentencia tiene, el razonamiento y el fallo del Supremo permiten poner en tela de juicio la opinión de quienes entienden que la doctrina del levantamiento del velo es un recurso técnico innecesario porque otros conceptos o mecanismos más ajustados a nuestra tradición jurídica permiten llegar a similares resultados que los que con aquélla se alcanzan. A diferencia de lo que ocurre con otras sentencias, aquí parece que a nada habría conducido acudir a formas de reflexión que girasen en torno a la idea de fraude, porque es de todo punto inverosímil pensar que EMAYA fuera constituida por el Ayuntamiento para dar lugar a confusiones (en el doble sentido de la palabra, de equivocación y de dificultad en identificar a la persona jurídica realmente responsable de los daños) como la que a todas luces sufrió la demandante antes de formular su reclamación judicial.

Vistas así las cosas, parece encontrar justificación que el Tribunal Supremo optase por la vía (en todo caso rodeada de cautelas y prevenciones) del levantamiento del velo. No obstante, cabe preguntarse si para llegar al mismo desenlace desestimatorio del recurso no podía haberse invocado por la Sala el principio de la buena fe como regla para el ejercicio de todo derecho subjetivo. En este caso, la facultad de EMAYA de oponer la excepción de prescripción - podría pensarse - habría de estar guiada por la idea de que la interrupción causada respecto al Ayuntamiento debía entenderse hecha respecto a la propia EMAYA, en virtud de las sustanciales concomitancias que dieron lugar a que el Tribunal Supremo dijera, nada menos, que EMAYA era un «órgano integrante» del Municipio. En todo caso, es una cuestión apta para el debate y no pretendo entrar en más profundidades.

2. Tiene notable parecido con el caso de la resolución que acabo de citar el de la sentencia de la Audiencia Provincial de Vizcaya de 20 de setiembre de 1988. En ella se acudió al levantamiento del velo como instrumento para considerar interrumpida la prescripción, aunque la declaración de voluntad en tal sentido no se dirigiese a la persona jurídica directamente responsable del daño.

Era demandante Doña María y demandados el Consorcio de Compensación de Seguros y RENFE. Se trataba de la reclamación de una indemnización de daños y perjuicios como consecuencia del accidente de 
ferrocarril sufrido por la actora. Esta había formulado intimación extrajudicial contra el Consorcio, como «asegurador obligatorio» de la compañía ferroviaria, pero en cambio no se había formulado declaración de voluntad de interrumpir la prescripción en cuanto a la propia RENFE.

El Juzgado había estimado la demanda; e interpuesto recurso de apelación por la representación de RENFE, la Audiencia lo desestimó, siendo ponente el señor Belloch Julbe.

La sentencia de la Audiencia hace expresa invocación de la del Supremo de 28 de mayo de 1984, reproduciendo sus pasajes más significativos, y dice — refiriéndose a RENFE — que «aparece como una simple forma para encubrir la creación de un ente filial puro y simple, externamente regido por el Derecho privado, pero en realidad, internamente, de la pertenencia de la Administración». Más adelante añade la sentencia que la concreta forma de la cual el Estado articula o instrumentaliza la gestión de los servicios públicos, manteniendo de manera efectiva el «control unitario y total de los diferentes organismos», no puede ser utilizada ulteriormente por el propio Estado (a través de la «ficción», en este concreto aspecto, de la creación de «personas jurídicas autónomas») para, en perjuicio de terceros de buena fe, «sustraerse a los efectos interruptivos de la interpelación realizada contra cualquiera de tales "organismos", máxime cuando, como en el caso de autos, se trata de dos "organismos" (el Consorcio como "organismo autónomo del Estado" adscrito al Ministerio de Hacienda, RENFE como "personalidad de Derecho público" que, aunque actúe en régimen de "empresa mercantil", depende real y efectivamente en gran medida del Gobierno a través del MOPU) que, además de formar parte de la llamada "constelación administrativa", se encuentran íntimamente relacionados entre sí, al configurarse el Consorcio como el asegurador obligatorio de RENFE, de donde se infiere, así pues, de nuevo, que la diligente reclamación administrativa llevada a cabo ante uno de tales organismos debe valer como reclamación extrajudicial a los efectos interruptivos de la prescripción prevenidos en el artículo 1.973 del Código civil».

3. Estas dos sentencias que acabo de citar recuerdan algunas otras del orden jurisdiccional contencioso-administrativo, en que los Tribunales han efectuado diversas formas de «penetración» en una personificación jurídico-privada para llegar a la Administración matriz de la que aquélla depende. Es el caso de la sentencia de la Sala Cuarta de 16 de marzo de 1973 (ponente señor Ponce de León), en que el Supremo calificó de contrato administrativo al otorgado por una sociedad anónima municipal, «en lugar de ser el propio Ayuntamiento el que de forma directa lo concertara», declarándose por ello la competencia de la jurisdicción contencioso-administrativa para conocer del asunto. 
En la sentencia de 12 de junio de 1984, también de la Sala Cuarta (ponente señor Martín del Burgo), el Supremo, al referirse a un Patronato Municipal de Vivienda, dijo que su constitución «no pasa de ser un recurso técnico jurídico para agilizar y facilitar su gestión específica, pero sin que ello venga a representar, sobre todo en la práctica, que este ente pueda ser como un auténtico "penitus extranei" respecto al Ayuntamiento matriz, como lo evidencia el que los principales miembros de la Junta Rectora de aquél lo son por razón de los cargos desempeñados en éste».

Repárese en que en las dos sentencias que acabamos de mencionar se practica una genuina operación de levantamiento del velo, aunque sin utilizarse explícitamente esta terminología.

Parecido criterio se siguió en la sentencia de 2 de abril de 1986 (así mismo de la Sala Cuarta, ponente señor Reyes Monterreal), en un caso en que se discutía sobre la incompatibilidad o no de una persona para desempeñar el cargo de concejal de un Ayuntamiento (porque a la vez estaba ligado mediante contrato de trabajo, como médico, con el Patronato titular del Hospital Municipal). La Sala acepta la premisa de que las fundaciones, por el hecho de su constitución, adquieren la personalidad propia que se alegaba, añadiendo que por regla general el personal dependiente de ellas no puede entenderse que depende de quien instituye la fundación. Pero advierte el Tribunal que esta conclusión no puede ser aplicada en casos como el que allí se enjuiciaba, en que el objeto de la fundación era la realización de un servicio público. Porque, dice la Sala, aquella independencia no puede ser invocada «cuando el servicio no deja de prestarse por gestión directa de la Corporación, aunque al efecto se cree una Fundación pública del que sigue propiamente municipalizado, aunque adoptando una de las modalidades previstas para esta gestión directa por el 67 del propio Reglamento, por más que materialmente la efectúe el elemento personal que constituye el Patronato creado a tal fin, no exento, por ello, de la fiscalización y tutela del Ayuntamiento que lo crea, lo que, en cualquier caso, no supone que ello engendre otra personalidad distinta que la del propio servicio, habida cuenta que la misma se atribuye a éste y no a un ente distinto del Ayuntamiento por el artículo 85 del texto reglamentario, deviniendo así el servicio simplemente "personalizado" según el 86 , con un patrimonio especial afecto a los fines específicos de la institución creada, pero cuya titularidad dominical el propio Ayuntamiento conserva, que se rige por un Estatuto aprobado por la Corporación misma y con una dirección y administración a la que ésta no es ajena».

En este orden jurisdiccional contencioso-administrativo, la Sala Cuarta, en sentencia de 9 de junio de 1988 (ponente señor Gónzalez Navarro), hizo explícita mención del «levantamiento del velo»; dijo que era 
necesario hacerlo para apreciar la auténtica relación que unía al Ayuntamiento de Barcelona con las fundaciones públicas que de él dependían. Se trataba de determinar si, como consecuencia de las relaciones entre el Patronato Municipal de Guarderías Infantiles de Barcelona y el Ayuntamiento de aquella ciudad, la primera de dichas entidades reunía o no los requisitos para gozar de una subvención del Ministerio de Trabajo y Seguridad Social. La Sala, después de invocar el «alzamiento del velo» de la personalidad jurídica, concluye que la relación entre el Ayuntamiento y las fundaciones públicas que de él dependen es una relación fiduciaria, en cuya virtud el ente matriz «confía» al Patronato la realización de una finalidad concreta, en este caso la guardería infantil. Declara la sentencia que «la personalidad de la fundación, por más que sea un instrumento útil de cara a facilitar una más fácil gestión, no puede hacer perder de vista el carácter de simple órgano que en las relaciones internas tiene aquélla. En consecuencia, la cocina del Ayuntamiento es cocina del Patronato y de las demás organizaciones — personificadas o no- dependientes de aquél».

En este orden de cosas, interesa señalar que la sentencia de la Sala Primera del Tribunal Supremo de 5 de diciembre de 1990 (ponente señor Fernández Rodríguez) utilizó el recurso del levantamiento del velo, aunque sin mentar esta expresión, para declarar la incompetencia de la jurisdicción civil en una demanda de impugnación de acuerdos sociales. La Sala desatiende la implícita alegación de que, por ser la demandada una sociedad anónima, era el orden jurisdiccional civil el competente para conocer del asunto, inclinándose, por el contrario, por la contemplación de lo que podríamos llamar «vertiente interna» de la sociedad anónima municipalizada de que se trataba en aquel caso.

4. Mas, como decíamos antes, ha sido sobre todo en el orden jurisdiccional civil donde la doctrina del levantamiento del velo ha tenido más amplia acogida.

Abierto el camino por la tan repetida sentencia de 28 de mayo de 1984, muchas han sido las que con posterioridad han recurrido a la doctrina que nos ocupa. Y no es el caso de pormenorizarlas aquí. Me limito a reproducir el criterio de sistematización u ordenación que he venido adoptando en mi obra antes citada. Es, desde luego, uno más de los posibles y quizá no el mejor, pero sólo como sugerencia me permito proponer esa forma de catalogación.

Hay, en primer término, sentencias en que el «desentendimiento» de la persona jurídica es para extender la responsabilidad civil (en el sentido estricto de deber de reparar el daño) de una de ellas a otra o a los socios de la primera. En otras sentencias encuentro un hilo conductor consistente en que en ellas el levantamiento del velo permite descubrir la identi- 
dad entre los intereses de una persona jurídica y los de un sujeto individual, casi siempre a efectos de extender a este último las obligaciones formalmente incumbentes a aquélla. El denominador común de otras sentencias es el de haberse «descorrido el velo» de una persona jurídica para llevar a cabo valoraciones éticas de conductas, esto es, actos de enjuiciamiento que en principio sólo caben respecto a personas físicas; por ejemplo, para indagar sobre la buena o mala fe, para descubrir en la existencia de una dualidad formal de sociedades un instrumento para engañar o desorientar a proveedores, o para concluir en la efectiva violación de un pacto de no concurrencia, etc. Otro grupo de resoluciones se caracteriza porque en ellas el levantamiento del velo es para contemplar la persona jurídica como objeto, no como sujeto de la relación controvertida en cada caso.

Un conjunto distinto de sentencias es el de aquellas en que el protagonismo corre a cargo de una sociedad de un solo socio o, en general, de una persona jurídica de único miembro. También son numerosas las sentencia civiles en que el levantamiento del velo entra en juego en casos de tercería de dominio o en que, en términos más amplios, es una regla procesal la que ha de ser aplicada de una u otra forma. Hay también sentencias susceptibles de catalogarse en un grupo autónomo, por cuanto el levantamiento del velo determina una u otra orientación del asunto en relación con actos fiduciarios. No faltan sentencias en que el levantamiento del velo se lleva a cabo en problemas relacionados con el disfrute de bienes. Por fin, dentro de esta personal clasificación, no pocas resoluciones hacen uso del levantamiento del velo para evitar consecuencias injustas que pudieran resultar de la confusión entre las denominaciones de personas jurídicas distintas.

5. No puede dejar de mencionarse el hecho de que antes de la sentencia de mayo de 1984 hubo otras civiles que, sin declararlo con estas palabras, implicaron alguna forma de «desentenderse» de la persona jurídica o de «adentrarse» en su interioridad.

Es el caso de la sentencia de 30 de abril de 1959, siendo ponente el señor Murga Castro. Se trataba de la demanda planteada con motivo de un accidente de circulación y la Audiencia la había desestimado por falta de legitimación pasiva del dueño del vehículo en que se produjo el accidente, dado que con él no había celebrado el demandante contrato alguno. Pero el Tribunal Supremo concluye que son "ambas empresas una sola entidad, con una unidad patrimonial (por lo que) puede y debe el demandado responder de la culpa de su dependiente, en razón a que no debió confiarle, en beneficio del interés público, el servicio que le encomendó».

Otro precedente interesante fue el constituido por la sentencia de 21 de febrero de 1969. En un problema que giraba en torno a una opción de 
compra, la Sala, siendo ponente el señor Taboada Roca, dijo que «no puede ampararse un fraude de ley para dejar de cumplir los contratos válidamente celebrados, máxime en una sociedad familiar y regida de hecho por el padre..., en la que su personalidad jurídica constituía una ficción legal..., por todo lo que no debe considerarse como un tercero frente al contrato litigioso».

En la sentencia de 8 de enero de 1980 se encuentra una expresión de lo que significa el levantamiento del velo de la persona jurídica, pero precisamente para no aplicarlo, esto es, para no llegar a las consecuencias que con su puesta en práctica procederían. Dice la Sala, siendo ponente el señor de la Vega Benayas, que «es correctamente admisible la posibilidad de investigar el fondo real de la situación, sin detenerse en la forma jurídica de la persona para, en atención a los individuos reales que la constituyen y a su posición, pronunciarse sobre los intereses en juego y su protección, de acuerdo con los principios que regulan la conducta contractual». Lo verdaderamente singular, como decíamos, es que el Tribunal Supremo lleva a cabo la «penetración» en la interioridad de la persona jurídica pero no para concluir en la existencia de intereses idénticos entre la sociedad anónima y sus socios, sino justamente para lo contrario, esto es, para sostener la afirmación de que entre sociedad y accionistas existía una genuina contradicción o dualidad de intereses.

Son sentencias en la misma línea, todavía más remotas, las de 12 de diciembre de 1950, 22 de junio de 1956 y 5 de mayo de 1958.

En la primera de ellas, siendo ponente don Mariano Miguel y Rodríguez, y con ocasión de valorarse la «mala fe» de la sociedad adjudicataria de una finca, la Sala dice que «no sería contraria a las reglas de la sana crítica la deducción ... de que los cuatro socios componentes de aquélla conocían los defectos y vicios de que adolecía el procedimiento y que necesariamente tenían que afectar a la validez de sus respectivos títulos adquisitivos». En suma, una interesante «comunicación» de la mala fe entre la sociedad y sus cuatro socios.

En el caso de la sentencia de 22 de junio de 1956, de la que fue ponente el señor Siboni Cuenca, se debatía sobre la validez y eficacia de un derecho de opción de compra constituido por los copropietarios de un molino, que luego aportaron sus participaciones a una sociedad creada por ellos mismos. El Supremo concluye que no era lícito oponer que la mala fe no se daba en la sociedad limitada así constituida, diciendo que, de no ser así, «se derrumbaría la seguridad de la contratación por el sencillo artificio de constituir una razón social con aportación de bienes que los propios aportantes, de manera voluntaria y libre, habían comprometido en el cumplimiento de obligaciones que contrajeron y que ocultaron 
al constituir la sociedad, lo que pugna con los más elementales principios de la Moral y del Derecho».

En cuanto a la sentencia de 5 de mayo de 1958, de la que fue ponente el señor Rodríguez Valcárcel, recayó en la demanda entablada contra un socio colectivo y además gestor de una compañía mercantil en comandita llamada «A.C. y compañía». Se decía que había usado mal de la facultad privativa de administrar y de la firma de la compañía, por haber aplicado los bienes de la misma para negocios de cuenta propia y de su familia, constituyendo, mediante las personalidades interpuestas de su mujer y de sus hijos, una sociedad anónima de la misma denominación, con el fin de suplantar a la comanditaria en su negocio y de apropiarse de él en beneficio de sus familiares. La Sala, refiriéndose al contrato sin causa o con causa ilícita, dice que el artículo 1.275 del Código civil da «un amplio concepto de la ilicitud causal en el sentido de oponerse lo pactado a las leyes o a la moral, norma que los Tribunales deben integrar en cada caso con criterios objetivos extraídos del mismo ordenamiento jurídico y de concepciones todavía más altas que lo inspiran en calidad de principios éticos comúnmente adoptados, y entre ellos el de que nadie puede desposeer a otro sin la voluntad del despojado y por su propia decisión, cualquiera que sea el medio aparentemente empleado como no reprobado en ambas esferas de la Moral y de Derecho; y al afirmarse en el tercero de los pronunciados de la sentencia recurrida que la sociedad anónima "A.C. y compañía" fue formada con el propósito de absorber la comanditaria del mismo nombre "A.C. y compañía", sociedad en comandita, sin previas disolución y liquidación de ésta y de acuerdo social dirigido a la absorción, resulta evidente y certera la calificación hecha en la instancia, no impugnada con éxito en casación, de la ilicitud causal con sus consecuencias naturales».

6. No es necesario encarecer la importancia que la técnica del levantamiento del velo viene teniendo en la resolución de asuntos propios de la jurisdicción social o laboral. Abundan en ella las sentencias en que, haciéndose o sin hacerse expresa mención de esta doctrina (es habitual la cita de sentencias del orden civil en tal sentido), se lleva a cabo la penetración en la interioridad de una sociedad mercantil, esto es, la acción de desvelar el substratum personal de empresas constituidas en forma de sociedad. Son, sobre todo, asuntos en que estaba en juego el principio de «unidad de empresa», con la variada terminología que en este terreno es usual («conjunto económico único», «grupo empresarial», «grupo de empresas», etc.), cuestión en la que una considerable casuística ha dado lugar a dificultades de definición o delimitación que, a mi juicio, aborda con gran solvencia la sentencia de la Sala Cuarta de 30 de junio de 1993, muy digna de tenerse en consideración en la materia que nos ocupa. 


\section{El «levantamiento del velo» como instrumento para extender la responsabilidad. A) Sentencias que lo hacen. B) Sentencias que lo rechazan y advierten de la cautela necesaria en esta materia}

A continuación menciono algunas sentencias que se han acogido al levantamiento del velo de una persona jurídica (de ordinario una sociedad) para «comunicar» su responsabilidad patrimonial a la de los socios componentes de la misma, o a alguno de ellos. Luego dedico una breve atención a sentencias que, por el contrario, no acceden a esa «ruptura del hermetismo» de la persona jurídica y advierten de la excepcionalidad de cualquier criterio judicial conducente a ese resultado, así como de la cautela que debe presidir la actuación de los Tribunales en este punto.

A) Resoluciones del primer tipo de los dos mencionados.

1. En ese primer grupo es interesante la sentencia de 4 de marzo de 1988. Siendo ponente el señor Serena Velloso, la resolución sale al paso del intento de la recurrente de eludir la identificación entre las cuatro sociedades anónimas encartadas en el asunto, que la sentencia de instancia había establecido como base fáctica de la condena de la única sociedad formalmente demandada y por ello condenada.

La sentencia, en la parte que interesa, comienza con el siguiente razonamiento: «También ha de alinearse, en pro del mantenimiento de la condena que pronuncia la sentencia impugnada, la doctrina de esta Sala, que no ha vacilado en apartar el artificio de la sociedad para decidir los casos según la realidad. El Tribunal de instancia deja afirmado, según las transcripciones que se ofrecen en el primero de los presentes fundamentos, "que las tres sociedades anónimas, pese a su apariencia formal, pertenecen a una sola persona o familia, como lo confirman su propia denominación, la escasa diferencia, por no decir identidad, de su objeto social, el hecho de tener el mismo Presidente y como Administrador un empleado a veces de una u otra y hasta la ubicación de la industria en las mismas naves o en otras adyacentes formando una unidad"; estas tres sociedades y solamente ellas concurrieron a formar en 1973 la Asociación AGEMAC y en 1978 a constituir la anónima de igual nombre. Según la jurisprudencia aludida, formada entre otras por las sentencias de 28 de mayo de 1984, 27 de noviembre de 1985,9 de julio de 1986 y 16 de febrero y 24 de setiembre de 1987, en el conflicto entre seguridad jurídica y justicia, valores hoy consagrados en la Constitución ...» (sigue la reproducción textual de lo que con estas mismas palabras iniciales dijo la sentencia de la Sala Primera de 28 de mayo de 1984, tantas veces citada por nosotros).

2. Sentencia de 5 de junio de 1990.

El juicio tuvo su origen en la demanda incidental de oposición a una declaración de quiebra entablada contra Banco X., pretensión que fue de- 
sestimada en el Juzgado y en la Audiencia. El Tribunal Supremo declara no haber lugar al recurso, siendo ponente Don Jaime Santos Briz.

La sociedad quebrada recurrente invocó el hecho de no encontrarse en situación de insolvencia, aduciendo que ésta podría darse en sus dos únicos socios, según se desprende del no muy expresivo relato de los fundamentos de Derecho, que es la parte de que disponemos. Lo cierto es que la sentencia, en uno de ellos, dice:

«El motivo segundo, con idéntico amparo procesal, y con el mismo reproche que se hizo al primero, acusa la infracción del artículo 1.025 del Código de comercio de 1829, insistiendo en que no puede concluirse que la empresa haya efectuado una cesación de pagos, afirmación que se hace olvidando los hechos probados, que no han sido impugnados en casación por el cauce adecuado, y se afirma o se insiste también en la dualidad de personas entre el socio y la sociedad, de donde es evidente que, en casos como el ahora debatido, la alegación es inútil en cuanto la identificación de socio y sociedad no puede negarse, al margen de la teoría de la personalidad independiente de las sociedades frente a los socios individuales que las forman, y serían un summum jus summa injuria exigir un nuevo proceso contra las dos personas físicas únicas que componen la persona jurídica social debatida, o viceversa.»

3. Sentencia de 20 de junio de 1991.

El caso que dio lugar a este pleito era particularmente complejo. Doña María del Carmen D.P. pidió que se condenase a la Caja de Ahorros y Monte de Piedad de Barcelona (hoy, La Caixa) al pago de determinadas cantidades, accediendo el juzgado a ello plenamente. La entidad demandada apeló sólo el pronunciamiento respecto al abono de 11.758.814 pesetas, que la actora afirmaba haber recibido como fiduciaria de O., S.A., para la compra de determinados valores bursátiles, ordenando posteriormente su venta. Venta que fue llevada a cabo pero ingresando la Caja tal importe en la cuenta corriente de S.P., S.A., error que no fue enmendado, lo que obligó a la demandante a reintegrarlo a O., S.A. Por esta razón, la actora reclamaba la citada cantidad, entre las demás de la demanda, en concepto de daños y perjuicios.

La Audiencia estimó el recurso y sentó que había existido «un claro y burdo montaje urdido entre la actora y su esposo para conseguir el ilícito beneficio de un cobro al que no podían tener el más mínimo derecho, por tratarse de una pura invención o maniobra fraudulenta», a cuyo fin la Audiencia se basaba en las interrelaciones existentes entre la demandante, su marido y las dos sociedades expresadas. A tal efecto, la Audiencia había tenido en cuenta los siguientes elementos de hecho: 1) La actora había otorgado el 19 de febrero de 1973 a favor de su marido un poder general que seguía vigente; 2) el citado esposo era apo- 
derado y único administrador de las sociedades S.P., S.A., y O., S.A., de las que además era accionista la demandante; 3) el 10 de agosto de 1983, la actora y su esposo suscribieron una póliza de afianzamiento de todas las operaciones a realizar por S.P., S.A., y O, S.A., hasta un límite de 105.000.000 de pesetas; 4) la orden de venta de aquellos valores fue firmada por el marido de la demandante con indicación del número de cuenta en que se había de ingresar el valor de los mismos, ingreso que aunque la actora dijo que se había hecho equivocadamente en la cuenta correspondiente a S.P., S.A., no permite olvidar que la disponibilidad de ambas cuentas correspondía a su esposo; y 5) el recibo de pago de O., S.A. había sido «creado» con posterioridad al acto de conciliación en el que se efectuaba ya la reclamación, siendo firmado por doña Carlota D., hermana de la demandante. De todo ello concluyó la Audiencia que la deuda era improcedente, por no haberse probado la intervención de la actora como «fiduciaria», ya que, por ser accionista de las dos sociedades, no era «tercera particular» a la concreta relación de «encargo», sino absolutamente interesada y beneficiada en la misma, tal y como ficticiamente se había instrumentado. Añade la Audiencia que el ingreso de los citados 11.758 .414 pesetas en la cuenta corriente de S.P., S.A., en lugar de en la de O., S.A., no implicaba ninguna desviación del reintegro o de la devolución, por cuanto, en definitiva, todo convergía en la misma persona que administraba y disponía de todos los «patrimonios», afectados además a la obligación de cobertura asumida en la póliza de crédito, siendo de resaltar — añade la Audiencia- «el abuso, fraude y desconocimiento de la más mínima ética, decoro y señorío que debe presidir toda actuación de un derecho» y que «el engaño, montaje o apariencia, al quedar desmontado desde el análisis de la auténtica realidad, obligaba a revocar la resolución recurrida».

Interpuesto recurso de casación por la demandante, el Tribunal Supremo declara no haber lugar al mismo, siendo ponente el señor Fernández Cid de Temes.

En su fundamento jurídico segundo, la sentencia hace unas interesantes consideraciones acerca del significado que, en general, merece el concepto de fraude de ley. Dice al respecto:

«... pues el fraude de ley civil lo que exige precisamente es la concurrencia de una serie de actos que, pese a su apariencia de legalidad, violen el contenido ético de los preceptos o normas legales en que se amparan (SS. de 6 de febrero de 1957 y 1 de abril de 1965), habiendo incluso declarado esta Sala que no es preciso que la persona que realice el fraude de ley tenga intención o conciencia de burlarla (S. de 13 de junio de 1959); en definitiva: no parte la sentencia recurrida de la existencia de un ilícito penal, sino que del análisis conjunto de los hechos llega a la conclusión de 
que concurre un ilícito civil encuadrable en el fraude de ley, pues el dinero no fue o se quedó en el patrimonio de la Caja, sino a una sociedad de la que el marido de la actora tenía la misma disponibilidad que la de su propio patrimonio, el de su esposa y el de la sociedad que debiera haber sido destinataria, respondiendo todos, e incluso las cédulas hipotecarias, de las operaciones de expresadas sociedades, cual se desprende de la simple lectura de la póliza de afianzamiento solidario y sus anexos, todo lo cual valora conjuntamente en uso de una potestad que le es propia, todo lo cual se examinará con más detalle al analizar la conducta fraudulenta».

Pero es en el fundamento jurídico cuarto de la sentencia donde la Sala Primera formula las manifestaciones que nos interesan en torno al levantamiento del velo de la persona jurídica. Dice al respecto la Sala:

«e) La práctica de penetrar en el substratum personal de las entidades o sociedades a las que la ley confiere personalidad jurídica propia, con el fin de evitar que al socaire de esa ficción o formal legal se puedan perjudicar intereses privados o públicos como camino del fraude (artículo 6.4 del CC) o la conducta fraudulenta en general, admitiéndose la posibilidad de que los jueces pueden penetrar (levantar el velo) en el interior de esas personas cuando sea preciso para evitar el abuso de esa independencia (artículo 72 CC), en daño ajeno o de los derechos de los demás, fundamento del orden público y de la paz social, es doctrina jurisprudencial consolidada (SS. de 4 de marzo de 1988, 24 de setiembre de 1987, o 5 de mayo de 1958 y 28 de mayo de 1984, por citar sólo algunas).»

A renglón seguido, el Tribunal Supremo viene a hacer unas muy atinadas consideraciones sobre la aplicación de la figura del fraude de ley a las particularidades del caso. Dice la Sala:

«) El fraude es sinónimo de daño o perjuicio conseguido mediante un medio o mecanismo utilizado a tal fin, valiendo tanto como subterfugio o ardid, con infracción de deberes jurídicos generales que se imponen a las personas, implicando, en el fondo, un acto contra legem, por eludir las reglas del Derecho, pero sin un enfrentamiento frontal, sino, al revés, buscando unas aparentes normas de cobertura o una cobertura indirecta, respetando la letra de la norma, pero infringiendo su espíritu, de forma que el "fraus alterius o fraus hominis" implica, con carácter general, un "fraus legis", pudiendo afirmarse que las normas citadas en el motivo que se analiza sólo tienen esa finalidad de normas de cobertura, por lo que la Audiencia procedió conforme al Código civil en su artículo 6.4 y los generales del abuso o mala fe al impedir que se alcanzase el efecto defraudatorio de pagar dos veces a quienes vienen ligados por un solo interés, cabiendo la destrucción del error con un simple trasvase de cuentas, dado que el marido de la actora tenía la disponibilidad de todos los patrimonios, pudiendo evitar el enriquecimiento injusto que se pretende (ver sentencia de 30 de marzo de 1988).» 
4. Sentencia de 5 de julio de 1991.

Como por desgracia ocurre algunas veces, la lectura de los fundamentos de Derecho de esta sentencia no permite hacerse cargo cabalmente de lo que en ella se trataba. Lo que está claro es que la parte actora había entablado demanda contra dos esposos y contra una sociedad anónima de la que estos últimos eran únicos socios. El Juzgado, estimando la demanda, condenó solidariamente a los esposos demandados y a la sociedad anónima a pagar las cantidades reclamadas. La Audiencia desestimó el recurso de los demandados en su integridad. Interpuesto recurso de casación, el Tribunal Supremo declaró no haber lugar al mismo, siendo ponente el señor Marina Martínez-Pardo.

Lo que se desprende de la lacónica descripción fáctica de esta sentencia es que se trataba de la reclamación basada en un contrato en el que, al parecer, no había sido parte - formalmente hablando — la sociedad demandada. La lectura del fundamento jurídico segundo lleva a la conclusión de que los esposos demandados habían constituido la sociedad anónima con el exclusivo propósito de llevar a cabo una actividad que luego formalizaron ellos personalmente, es decir, a título individual o como personas físicas.

Lo cierto es que el párrafo primero de ese fundamento sirve al Tribunal Supremo para invocar un criterio, que se dice de la propia jurisprudencia, por cuya virtud la limitación de responsabilidad de las sociedades mercantiles no puede mantenerse en algunas de ellas (esto es, en algunos casos), añadiéndose que se trata de supuestos en que «debe descorrerse el velo de la personalidad».

Es lástima que la sentencia no sea más explícita, porque la afirmación general de que la limitación de responsabilidad de una sociedad anónima no puede mantenerse en ciertos casos parece requerir la puntualización de a qué casos se refiere la Sala del Supremo. No ocurre así en la presente sentencia, sino que se formula el principio antes mencionado, que se denomina «criterio tantas veces sostenido por esta Sala», sin mayores puntualizaciones.

Lo que parece claro es que, en cualquier caso, no puede romperse con el principio de limitación de responsabilidad de una sociedad anónima por la simple circunstancia (que es la única que se menciona en esta resolución) de que sus únicos socios sean esposos entre sí. Dicho de otro modo, la generalización en términos absolutos de esa afirmación parcial de la sentencia podría conducir a conclusiones inaceptables y que a todas luces no ha pretendido formular la resolución que nos ocupa.

5. Sentencia de 12 de noviembre de 1991.

Se trataba de la demanda formulada por «M» contra «LSBV», en reclamación del importe de los envases que la sociedad demandante había vendido y que habían sido remitidos para ser rellenados con berberecho 
elaborado en Holanda, país de origen de la compradora, con ulterior reenvío a España, a casas importadoras de nuestra nación. La sociedad demandada se opuso a la demanda alegando exclusivamente que la compradora no había sido ella sino «SAL», de lo que se extraía la conclusión de su falta de legitimación pasiva (la de la propia demandada). La sentencia del Juzgado desestimó la demanda. Interpuesto recurso de apelación, la Audiencia, revocando la sentencia de primera instancia, estimó íntegramente la demanda. Formulado recurso de casación por la sociedad demandada, el Tribunal Supremo declaró no haber lugar al mismo, siendo ponente el señor Malpica y González-Elipe.

La sentencia, después de reproducir el ya muy conocido pronunciamiento doctrinal sobre el levantamiento del velo, en los términos en que lo formuló la sentencia de 28 de mayo de 1984 (aunque la cita es de otras resoluciones posteriores), declara aplicable esa doctrina al caso enjuiciado, en el que - dice la Sala — «se ha patentizado por la vía de hecho esa ubicuidad, ambigüedad y suplantación recíproca de las dos entidades mercantiles independientes que denotan, al menos en el negocio que nos ocupa, una identidad de intereses fruto de un entramado subjetivo e interno común a ambas».

Es lástima que la fundamentación jurídica de esa sentencia no arroje más luz acerca de los criterios que movieron, tanto a la Audiencia como al Supremo, a utilizar la técnica del levantamiento del velo y llegar a las conclusiones a que ambas Salas llegaron. No obstante, de la lectura del fundamento jurídico cuarto se desprende que para el Tribunal Supremo el criterio decisivo no fue, desde luego, el hecho de que las dos sociedades tuvieran el mismo director, sino la circunstancia de que la sociedad que había llevado a cabo el envasado de los productos en Holanda no era la que había recibido los envases objeto de la compraventa del pleito. El Tribunal Supremo añade que no existe justificación ni explicación en autos de esa dualidad de comportamientos, que es la base de la conclusión de que ambas sociedades encubrían los mismos intereses, es decir, que se trata de una dualidad ficticia.

Estimamos que muy serios y fundados tuvieron que ser los motivos del Supremo para formular este razonamiento, porque, en principio, el hecho de que una sociedad fuera la compradora de los envases para enlatar los berberechos, y otra distinta la que los envasara y comercializara, podía ser consecuencia de algo tan frecuente y normal como es que la primera vendiera a la segunda tales envases para los fines comerciales de esta última. No obstante, parece que en lo que hay que fijarse es en el dato de que el Tribunal Supremo pone el énfasis en que no se ha probado en autos la llamada «dualidad de comportamientos», palabras un tanto ambiguas a nuestro juicio pero que probablemente quieren referirse al 
hecho de que si entre la sociedad compradora de los envases y la que llevó luego a cabo el enlatado de los berberechos hubiese habido algún tipo de relación contractual (la citada de compraventa de envases), esa relación contractual podía haberse acreditado cumplidamente por parte de la demandada para probar en debida forma que su traída al pleito había sido indebida o injustificada.

Dicho con otras palabras, parece que en esta sentencia tenemos que leer entre líneas y suponer que la Sala Primera contó con elementos de juicio suficientes para concluir que la utilización de dos nombres sociales diferentes había sido, exclusivamente, con el propósito de engañar a la parte vendedora de los envases demandante y, en definitiva, para intentar sustraerse a la obligación de pago del precio de tales objetos.

6. Sentencia de 12 de febrero de 1993.

Se trataba de la demanda de mayor cuantía planteada por R., S.A., contra R.P., S.A., que a la vez formuló reconvención. El pleito versaba sobre nulidad de contrato. En primera instancia se desestimó la demanda y se estimó parcialmente la reconvención. La Audiencia confirmó la sentencia del Juzgado, con la variación de condenar a la actora reconvenida al pago de una cantidad a determinar en ejecución de sentencia. Interpuesto recurso de casación por la actora, el Tribunal Supremo declaró no haber lugar al mismo, siendo ponente el señor Albácar López.

La sentencia esgrime dos grupos de razones para desestimar el recurso. Como «razón primera» se formulan por la Sala las tan reiteradas declaraciones de la sentencia de 28 de mayo de 1984. Luego se hace mención de pronunciamientos más recientes, empezando por el de la sentencia de 27 de noviembre de 1987, que consideró que el sujeto pasivo de la deuda reclamada era el demandado y no la sociedad de que era único socio, y ello con independencia de la apariencia jurídica creada con la constitución de aquel ente colectivo. Otra sentencia citada es la de 9 de julio de 1986, que «prescindió de la forma social por la "particular composición de la sociedad recurrente"».

En segundo término, en aplicación de todo ello al caso entonces enjuiciado, la sentencia dice:

«Que en el supuesto que nos ocupa, y si se parte de los hechos que la resolución recurrida reputa probados y que no han sido combatidos en esta vía, de que la actora incumplió su obligación de no vender los productos a que alude la cláusula sexta a través de una entidad "directamente vinculada con ella"; "que tal entidad estaba dirigida por las mismas personas", que la actora tiene en ella "una participación superior al 41 por 100"; que celebra alguno de sus Consejos de Administración "en su domicilio de León" y que "no tienen absolutamente separados sus ámbitos de relaciones mercantiles", necesario resulta concluir que la actuación de la actora a través de otra en- 
tidad relacionada con ella en el modo indicado comporta un ejercicio antisocial de su personalidad con daño para terceros, permitiéndole cumplir un compromiso adquirido a través del mecanismo de imputar sus actos a una sociedad que, a los efectos que nos ocupan, debe ser reputada como directamente relacionada con la actora, por lo que la resolución recurrida, al así estimarlo y condenar a la actora reconvenida al abono de los daños originados por su incumplimiento, en modo alguno infringió los preceptos citados en este primer motivo, que debe ser, por ello, desestimado.»

Se observará que esta sentencia hace explícita aplicación de la doctrina del levantamiento del velo de la persona jurídica, en el concreto aspecto de determinar que la «penetración en el substrato» de la sociedad demandante y de «Rubiera Burgos, S.A.», constituye una forma de acreditar que la demandante había incumplido su obligación contractual (para con la demandada) de no vender sus productos en Asturias a través de compañías vinculadas a ella. Por decirlo de otro modo, la Sala Primera utilizó la técnica del levantamiento del velo para determinar lo que significa o lo que se puede entender por «vinculación» entre sociedades, a todas luces a efectos del respeto a un pacto de exclusiva como el que sin duda, en este caso, había existido entre demandante y demandada.

7. Sentencia de 12 de marzo de 1993.

En esta sentencia, que declaró no haber lugar al recurso de casación formulado por los demandados y de la que fue ponente el señor Morales Morales, se emite la afirmación de que «la normativa reguladora de las sociedades anónimas no puede ser amparadora de la conducta de mala fe negocial con que los demandados han venido actuando».

Los demandados, personas físicas, habían comprado unas mercancías en nombre propio y ocultado la existencia de una sociedad formada por ellos, existencia que luego alegaron en el pleito para que se desestimara la demanda contra ellos dirigida. El Supremo reconoce la «operación de confusionismo» creada por los interpelados, ocultando a la actora que las mercaderías hubieran sido adquiridas para la sociedad anónima que dijeron (y probaron) existir.

La sentencia, como conclusión de sus razonamientos dice:

«.. y sin olvidar en modo alguno la normativa reguladora de las sociedades anónimas (en cuanto a su personalidad jurídica propia y en cuanto a la no responsabilidad personal de sus accionistas por las deudas sociales), ha entendido correctamente que dicha normativa no puede ser utilizada como amparadora de la conducta de mala fe negocial con que los demandados han venido actuando, al contratar en nombre propio con la vendedora, ocultando a ésta que las mercaderías las compraban para dicha sociedad anónima y luego pretender cobijarse en la existencia de ésta para eludir el pago del precio de las mismas». 
La sentencia no utiliza la expresión «levantamiento del velo» para llegar al desenlace desestimatorio del recurso. Es posible que la Sala acierte al no hacer dicha invocación, porque probablemente es éste uno de los casos en que con más claridad se manifiesta que la doctrina del levantamiento del velo constituye un recurso técnico innecesario cuando el conflicto enjuiciado puede ser resuelto - con el mismo desenlace-mediante la utilización de principios, conceptos, instituciones o criterios de corte «tradicional», esto es, no necesariamente sustentados en ninguna actividad de «penetración» en la interioridad de una persona jurídica.

En síntesis, no era un caso de constitución de una sociedad mercantil para la legítima satisfacción de los intereses de los socios, sino que de lo que propiamente se trataba era de que dos personas físicas, que habían aparentado comprar unas mercancías en su propio nombre, llegado luego el momento del pleito alegaron que tales adquisiciones las habían realizado para una sociedad anónima de la que ellos mismos eran socios.

8. Sentencia de 16 de febrero de 1994.

Interpuesta demanda contra una Caja de Ahorros y don Joaquín, el Juzgado y la Audiencia condenaron a los demandados al pago solidario a la actora de la cantidad reclamada, más intereses legales. Interpuesto recurso de casación, el Supremo declaró no haber lugar al mismo, siendo ponente el señor Gullón Ballesteros.

La sentencia que nos ocupa hace aplicación de la doctrina del levantamiento del velo, amparándose en la circunstancia de que por el codemandado recurrente en casación se había hecho «abuso» de la personalidad jurídica de una compañía mercantil mediante el sistema de aparecer a veces como persona física y otras como persona jurídica de su mismo nombre en sus relaciones mercantiles.

$\mathrm{Y}$ a este respecto dice la sentencia:

«... no se apercibe de que la sentencia que recurre ha confirmado la de primera instancia, haciendo una remisión expresa a ésta, que en su fundamento jurídico segundo (aunque la Audiencia por error dice tercero) resalta la conducta contraria a la buena fe del codemandado y ahora recurrente, que unas veces, según su conveniencia, aparece como persona física y otras como persona jurídica de su mismo nombre y, en consecuencia, aplica la doctrina de esta Sala sobre la necesidad del "levantamiento del velo de la persona jurídica", que aquí se traduce en que la sociedad y la persona física demandadas debe considerarse que son lo mismo, como no podía ser de otra manera cuando en autos se ve que es esta última la que hace y deshace, y la sociedad está constituida en un 80 por 100 por el recurrente, en un 10 por 100 por su padre y en otro 10 por 100 por otra persona». 
9. Sentencia de 30 de julio de 1994.

Construcciones Arvill, S.A., acreedora de la promotora Ibérica Osuna, S.A., como consecuencia de un contrato de obra, cedió su crédito a Construcciones El Partal, S.A., cesión notificada notarialmente a Inmobiliaria Osuna, S.A. Sosteniendo que Ibérica Osuna, S.A., e Inmobiliaria Osuna, S.A., son una misma persona jurídica y que la primera tenía conocimiento de la cesión del crédito, Construcciones El Partal, S.A., demandó a Construcciones Arvill, S.A., a Ibérica Osuna, S.A., y a Inmobiliaria Osuna, S.A., pidiendo sustancialmente que se declarase válida la cesión del crédito contra la compañía del grupo inmobiliario Osuna que resultase probado que era la promotora de la urbanización del caso (bien fuera Inmobiliaria Osuna, S.A., bien Ibérica Osuna, S.A.) y condenándola al pago del crédito en cuestión.

El Juzgado de Primera Instancia había estimado parcialmente la demanda contra Ibérica Osuna, S.A., absolviendo de la misma a Inmobiliaria Osuna, S.A., y a Construcciones Arvill, S.A. Apelada la sentencia por Ibérica Osuna, S.A., la Audiencia la revocó, absolviendo a las demandadas de las peticiones de la demanda.

Interpuesto recurso de casación, el Tribunal Supremo declaró haber lugar al mismo, siendo ponente el señor Gullón Ballesteros. La Sala Primera, considerando acertadas las valoraciones del Juzgado, estimó la demanda hasta el importe señalado en la sentencia de primera instancia.

El segundo motivo del recurso denunciaba violación, entre otros, del artículo 1.253 del Código civil. Pues bien, el Tribunal Supremo acoge el motivo diciendo:

«En este punto debe ser estimado el motivo, porque de aquellos hechos ha de obtenerse necesariamente la conclusión de conocimiento de la cesión, de modo rigurosamente ineludible y obligado. Se dan, pues, las circunstancias que exige esta Sala para denunciar en casación la no aplicación de la prueba de presunciones (sentencias de 18 de julio de 1990 y las que se citan), y se revela correcta la establecida por el Juzgado de Primera Instancia. En efecto, si el acreedor notificó notarialmente la cesión de su crédito en el mismo edificio de Granada (edificio O.) donde tenían sus oficinas tanto Ibérica Osuna, S.A., como Inmobiliaria Osuna, S.A.; si recibió la notificación en ella la misma persona que llevaba la asesoría jurídica de ambas sociedades; si asumió la obligación de entregarla a quienes ostentasen representación suficiente de Ibérica Osuna, S.A., al hacerse cargo de la cédula con copia literal del acta notarial incluyendo carta protocolizada, pues así se lo advirtió el Notario actuante y nada rechazó, es de todo punto evidente que el cedente cumplió todo cuanto estaba en su poder para dar a conocer la cesión a la deudora cedida Inmobiliaria Osuna, S.A., sin que quepa pensar lógicamente que el asesor jurídico no sepa a qué se comprometía, y que incumpliese deberes obvios tanto de su 
cargo como de receptor de una notificación para su cliente. La Sala de Apelación niega el conocimiento, no porque estime no probados los hechos en que se asientan esas deducciones, sino porque considera que la notificación se hizo a Inmobiliaria Osuna, S.A., y no a Ibérica Osuna, S.A., que en su concepto son dos personas jurídicas distintas; pero traer a colación el hermetismo y absoluto aislamiento de las personas jurídicas -doctrina anticuada y sometida a continuas críticas y excepciones en su aplicación por parte de los autores y de la doctrina de esa Sala-, traer a colación, repetimos, estas ideas no debe oscurecer la realidad de lo que ocurre según la común experiencia, que en este caso hubiera llevado a rechazar la notificación si las personas jurídicas fuesen distintas.»

Leyendo estas palabras que acabamos de transcribir, parece claro que la sentencia está poniendo las bases de lo que en efecto viene a continuación, esto es, el desarrollo o aplicación de la doctrina del levantamiento del velo como instrumento para descubrir la «real identidad» existente entre las dos sociedades, Ibérica Osuna, S.A., e Inmobiliaria Osuna, S.A.

Así, el fundamento jurídico cuarto de la resolución dice en sus dos primeros párrafos:

«El motivo tercero, al amparo del artículo 1.692.5. ${ }^{\circ}$ de la Ley de Enjuiciamiento civil, acusa infracción de la doctrina de esta Sala, recogida en las sentencias que reseña, que impide que la persona jurídica pueda ser, considerándola aisladamente de sus componentes y sustrato patrimonial, un medio para defraudar la buena fe de terceros, causarles perjuicios, ejercitar abusivamente derechos o defraudar a la ley, y todo ello por considerar que si reúne los requisitos formales prevenidos en la legislación, nace una persona jurídica independiente de otras, con las que no puede confundirse; la personalidad jurídica se hace así hermética y aislada.

El motivo se estima, pues pocas veces se presenta un caso tan claro como el litigioso para ver hasta qué punto hay que penetrar en el sustrato de la persona jurídica y juzgar si efectivamente es una realidad independiente de la de otra persona jurídica, o por el contrario, al ser ese sustrato igual o muy semejante, la personificación no puede llevar a conceptuar como distintas a tales personas jurídicas. En efecto, según los certificados registrales que obran en autos, se tiene que el Consejo de Administración de ambas sociedades, Ibérica Osuna, S.A., e Inmobiliaria Osuna, S.A., lo constituyen las mismas personas, con el apellido Osuna, todos ellos menos una; casi en los mismos días, ambas sociedades acuerdan el traslado del domicilio social a un mismo lugar de Madrid; y el Consejero-Delegado de las dos sociedades es la misma persona, don Nicolás O.G. Por si fuera poca esa unidad de dirección de las sociedades (que es una característica que se pone siempre como muestra de identidad real de personas jurídicas), se tiene además que: a) las sociedades poseen sus oficinas administrativas, contables, comerciales en el mismo edificio de Granada, llamado edificio O.; b) el letrado que bastantea el poder al 
procurador de Ibérica Osuna, S.A., es el que comparece como representante legal de Inmobiliaria Osuna, S.A., para confesar por esta últi$\mathrm{ma} ; \mathrm{c})$ anteriores cesiones de crédito en que aparece como deudora cedida Ibérica Osuna, S.A., son notificadas a Inmobiliaria Osuna, S.A., sin que se haya intentado probar siquiera que por falta de identidad de deudores fueran rechazadas por la receptora de la notificación; d) anteriores órdenes de retención y embargo contra empresas acreedoras fueron dadas por los Juzgados a Ibérica Osuna, S.A., e Inmobiliaria Osuna, S.A., como deudoras indistintas, sin que tampoco conste que se protestase por esta última sociedad. En fin, son tantas las señas de identificación que se han dejado, que parece peregrino negar la identidad entre Ibérica Osuna, S.A., e Inmobiliaria Osuna, S.A.»

Estamos, pues, ante un genuino caso de puesta en práctica del levantamiento del velo; y con tal lujo de detalles, por parte de la sentencia, que hace que la conclusión sea irrebatible.

Ahora bien, no cabe dejar de mencionar lo que en el último párrafo de ese fundamento jurídico puntualiza la sentencia, extremo procesal digno de tenerse en cuenta como criterio para la forma de actuar ante hipótesis similares. Dice la Sala Primera:

«Sin embargo, la admisión que se hace del motivo examinado no puede llevar a un pronunciamiento condenatorio de Inmobiliaria Osuna, S.A., ya que fue absuelta de las peticiones de la demanda en primera instancia, y esa sentencia no fue apelada por la hoy recurrente, que consintió, pues, en su absolución, sin que, por otra parte, un codemandado pueda pretender la condena de sus codemandados, según doctrina reiterada y constante de esta Sala. La admisión no tiene más efecto que el de considerar que la cesión del crédito fue debidamente notificada a la deudora del mismo, por la identidad sustancial, aunque formalmente sean distintas, de Ibérica Osuna, S.A., e Inmobiliaria Osuna, Sociedad Anónima.»

10. Dentro de la materia en que nos encontramos, esto es, la de posible «propagación» de la responsabilidad de una persona jurídica a sus miembros, revisten particular interés las sentencias que versan sobre la llamada «sociedad de un solo socio».

A este respecto merecen ser citadas, con la obligada brevedad del caso, las siguientes sentencias:

La de 27 de noviembre de 1985, en que fue ponente el señor Pérez Gimeno. La Sala hace aplicación del levantamiento del velo de una sociedad anónima a la que se habían suministrado ciertas mercaderías por parte del actor. La sentencia, en el pasaje que interesa, dice:

«.. en cuanto, a su entender, si la relación jurídica objeto de esta litis se entabló directa y exclusivamente entre el recurrido como vendedor y la entidad Servicio Técnico de A., S.A., como compradora, entidad que no 
ha sido traída al proceso y, por tanto, sigue diciendo, se ignora si en tal hipótesis hubiera pagado, no puede condenarse al demandado como persona individual; y debe desestimarse porque si los juzgadores de instancia, valorando todas las circunstancias concurrentes deducidas de la apreciación del material de convicción aportado al proceso, entendieron que el directamente obligado al pago del precio de las mercancías era dicho demandado, no puede argumentarse como hace el motivo, dado que tal obligación presupone la existencia del vínculo contractual explícito o implícito entre los litigantes y, por tanto, no puede afirmarse que el señor A. fuera ajeno a la compraventa origen de la reclamación, y mucho menos puede seriamente plantearse la hipótesis del posible pago de la deuda por la sociedad en el caso de haber sido demandada cuando, según lo dicho anteriormente, el señor A. es el único accionista de tal entidad y su único gestor, por lo que tal argumentación exterioriza una conducta contraria al más elemental principio de buena fe que debe presidir las relaciones contractuales y la conducta procesal de las partes».

Son interesantes las sentencias de 16 de julio de 1987 y 13 de mayo de 1988, dictadas en casos sustancialmente iguales. Demandada en ambos pleitos la Caja Rural Cooperativa Agrícola San Isidro de Jumilla, y reclamándose por los respectivos actores el reintegro de las cantidades a que ascendían los saldos de sus libretas de ahorro, la entidad demandada adujo que las libretas de ahorro eran de la Caja Rural de Jumilla, Cooperativa de Crédito, entidad jurídica — se decía - distinta de la interpelada. Fueron ponentes, respectivamente, los señores Carretero Pérez y López Vilas.

Los pronunciamientos de la Sala Primera son también similares y se sintetizan en el siguiente texto:

«Con independencia de este principio, pero sobre semejante base ética, el citado artículo, en su apartado dos, manifiesta que no se puede amparar el abuso del derecho, en este caso apreciable en la pretensión de llevar a sus últimas consecuencias la personalidad jurídica, cuando esa personalidad oficial no responde a la realidad, pretensión de apariencia legal correcta, pero social y éticamente insostenible y que, en el caso presente, ha producido daño, lo que hace aplicable la doctrina legal que sobre el abuso del derecho tiene establecida este Tribunal en general (sentencias de fecha 5 de abril de 1986 y 14 de febrero de 1986, entre otras) y, en particular, sobre el abuso de la personalidad jurídica (sentencia de 28 de mayo de 1984, que mantiene la necesidad de desvelar las verdaderas situaciones en orden a la personalidad, para evitar ficciones fraudulentas), en evitación de que la confusión sembrada por sociedades que actúan en régimen de subordinación pueda perjudicar intereses de los acreedores de la subordinada, lo que lleva incluso a la orientación doctrinal de la responsabilidad solidaria, cuando no exista norma legal expresa. Como conclusión, la demandada ha realizado actos propios de 
decisivo contenido contractual en la situación de depositario y, contrariamente a la buena fe, ha tratado de contradecirlos para imponer, con abuso, una personalidad existente, pero no actuante, lo que obliga a desechar los motivos del recurso estudiados en este apartado.»

También es de interés la sentencia de 16 de octubre de 1989, en la que se deduce que la reclamación se basaba en la «carta de afianzamiento» prestada por la sociedad demandada en favor de otra y en razón a determinada operación mercantil. Estimada la demanda por el Juzgado y la Audiencia, el Tribunal Supremo declaró no haber lugar al recurso, siendo ponente don Rafael Casares Córdoba. Dice la sentencia:

«... no puede afirmarse la ajeneidad de la demandada a la deuda garantizada y sí, por el contrario, que siendo la garante titular de la totalidad de las acciones de la anónima deudora principal, los negocios de ésta no eran en absoluto extraños a aquella otra "cuyos asuntos y patrimonio, insiste con meridiano acierto y decisivo razonamiento el Juzgado inicial, eran gobernados, administrados y dirigidos" por la recurrente. De suerte que más bien se está en presencia de dos anónimas cuya apariencia formal no puede ocultar la realidad de una única pertenencia, circunstancia ésta contemplada en la doctrina científica y jurisprudencial ( $S$. de 4 de marzo de 1988) para entender que ha de penetrarse en el sustrato personal de las entidades en tal situación y "levantando el velo", impedir que, al socaire de una forma legal que las dota de independencia, se incida fraudulentamente (artículo 6.4 del Código civil) en los intereses de terceros burlando su buena fe o se posibilite un uso antisocial del derecho (artículo 7.2 del Código)».

En la sentencia de 3 de junio de 1991 se ventilaba una reclamación basada en los siguientes hechos:

Don Francisco Javier P.A., en su calidad de Consejero-Delegado de «L.L., S.A.», celebró con don Carlos S.M. un contrato de compraventa, que se instrumentó en documento privado, por el que el primero enajenaba al segundo una parte de una finca, que se concretó en un plano adjunto al contrato, cuya totalidad pertenecía a «A., S.A.», en el precio y condiciones que se estipularon. El destino de la parte de la finca comprada era el establecimiento de cien parcelas y viviendas unifamiliares. En su cláusula séptima se estipuló que «"L.L., S.A.” podrá resolver el presente contrato en el supuesto de que el Ayuntamiento, además de las aportaciones previstas y ya efectuadas de hecho, respecto de los terrenos del campo de fútbol, plaza y viales, exigiera nuevas aportaciones económicas». También consta en el contrato la manifestación hecha por el señor P.A. de que la totalidad de las acciones de «A., S.A.» son propiedad de «L.L., S.A.», mediante compra realizada el 12 de noviembre de 1980 ante Corredor de Comercio. 
Tras diversas vicisitudes en la ejecución del contrato, en que las partes contratantes y «A., S.A.» tuvieron posturas encontradas, don Carlos S.M. demanda a «L.L., S.A.» y «A., S.A.» el cumplimiento de lo convenido, otorgando la correspondiente escritura pública, además de otras peticiones que no tienen trascendencia para resolver este recurso. «L.L., S.A.» fue declarada en rebeldía y «A., S.A.» se opuso a la demanda, solicitando su desestimación, ya que no había sido parte en el contrato; y alternativamente, para el supuesto de que así no se considerase, formuló reconvención pidiendo la resolución del contrato en uso de la facultad que contenía su cláusula séptima.

El Juzgado y la Audiencia estimaron la demanda en cuanto a la obligación de las demandadas de cumplir lo convenido, rechazaron la indemnización de daños y perjuicios solicitada por el demandante y declararon no haber lugar a la reconvención. El Tribunal Supremo declaró haber lugar al recurso de casación, si bien en un extremo secundario, no en cuanto al fondo de la decisión. Fue ponente el señor Gullón Ballesteros. La Sala Primera dice, en relación con una de las vías argumentales utilizadas por ella, la del levantamiento del velo, lo que sigue:

«Por último, cabe aplicar también para rechazar los motivos la doctrina del "levantamiento del velo" de la persona jurídica, acogida por esta Sala en abundantes sentencias (SS. de 28 de mayo de 1984, 27 de noviembre de 1985, 16 de julio de 1987, 29 de abril y 13 de mayo de 1988, entre otras), que proscribe la prevalencia de la personalidad jurídica que se ha creado si con ello se comete un fraude de ley o se perjudican derechos de terceros, escudándose en que el ente social es algo distinto de sus elementos personales constitutivos. En la situación jurídica originada por la reunión en una sola mano de todas las acciones de una sociedad, que legalmente no es causa de disolución de la misma, es más fácil perpetrar este abuso, pues el socio único tiende a comportarse como si los bienes de la sociedad fuesen suyos y los terceros que contratan con él sobre ellos tampoco suelen preocuparse de más porque su voluntad es la voluntad social. En realidad, tanto uno como otros acostumbran a prescindir de los órganos sociales de representación, ya que o bien la tiene el socio como Administrador único o bien otra u otras personas físicas que son nombradas y cesadas a voluntad del mismo. En el caso de autos, "A., S.A." es una sociedad anónima cuyas acciones fueron adquiridas en su totalidad por "L.L., S.A.", en 1980, situación en la que seguían al instrumentarse el contrato de compraventa litigioso y sin que en el pleito se haya intentado probar que dicha situación jurídica ha variado. "L.L., S.A." disponía de la finca vendida, formalmente de "A., S.A.", como propia en el tráfico jurídico. Al pretender "A., S.A." que prevalezca su personalidad jurídica sobre la de sus componentes - "L.L., S.A."-, se defraudan los derechos del comprador recurrido, pues sería tanto como permitir una vulneración del artículo $1.256 \mathrm{del}$ Código civil, ya que "L.L., S.A.", que otorgó el contrato como vendedora, 
lo dejaría sin efecto unilateralmente, envuelta ahora su voluntad bajo la personalidad jurídica de "A., S.A.", que se utiliza para manifestarse en contra de su validez y vigencia. En otras palabras, contrata "L.L., S.A." y posteriormente esa última sociedad, cuya voluntad social es por entero la de "L.L., S.A.”, pretende alegar que no consintió. Es claro que este abuso de la personalidad jurídica en perjuicio de terceros no puede ser amparado.»

11. La alusión que acabamos de hacer a la figura de la sociedad de un solo socio obliga a plantearse la cuestión a la luz de la reciente reglamentación positiva de la misma en nuestra legislación sobre sociedades mercantiles.

La Ley de 23 de marzo de 1995, sobre sociedades de responsabilidad limitada, regula en sus artículos 125 a 129 (Capítulo XI) la denominada sociedad unipersonal de responsabilidad limitada. Debe advertirse, a la vez, que según la disposición adicional segunda de dicha Ley, apartado 23, se modifica la Ley de sociedades anónimas en el sentido de incluir un nuevo artículo (el 311) en el que se dispone que será de aplicación a la sociedad anónima unipersonal lo dispuesto en el Capítulo XI de la Ley de sociedades de responsabilidad limitada.

De los artículos 125 a 129 de la Ley de sociedades de responsabilidad limitada se desprenden las siguientes reglas:

De acuerdo con el artículo 125, el régimen de la sociedad unipersonal se aplica tanto para el supuesto de sociedades constituidas por un único socio, sea persona física o jurídica, como para el de la denominada «unipersonalidad sobrevenida», esto es, cuando constituida una sociedad por dos o más socios, todas las acciones - o todas las participaciones sociales- pasan a ser propiedad de un único socio.

El artículo 126 establece unos importantes requisitos de publicidad.

De un lado, es necesario hacer constar en escritura pública, que se inscribirá en el Registro mercantil, la constitución de la sociedad unipersonal, la declaración de tal situación como consecuencia de haber pasado un único socio a ser propietario de todas las acciones o participaciones sociales, la pérdida de tal situación (por volver a una situación de pluralidad de socios) o el cambio del socio único. En el caso de la declaración de la situación de unipersonalidad, además deberá identificarse el socio único.

Mientras subsista la situación de unipersonalidad, la sociedad deberá hacer constar expresamente su condición de unipersonal en toda su documentación, correspondencia, notas de pedido y facturas así como en todos los anuncios que deba publicar por disposición legal o estatutaria.

El artículo 127 se refiere a las particularidades de la Junta General en este caso.

El artículo 129 formula normas sobre la hipótesis de unipersonalidad sobrevenida. 
Por fin, la disposición transitoria octava se refiere a las sociedades unipersonales preexistentes, es decir, las que hubiere al día de entrada en vigor de la ley, el 1 de junio de 1995.

Pero lo que aquí nos interesa es el régimen de los contratos del socio único con la sociedad unipersonal, contenido en el artículo 128.

Ese precepto comienza estableciendo nuevamente importantes requisitos de publicidad. En efecto, los contratos deberán constar por escrito, deberán transcribirse en un libro-registro de la sociedad que habrá de estar debidamente legalizado y en la memoria anual deberá hacerse referencia expresa e individualizada a dichos contratos entre el socio único y la sociedad, con indicación de su naturaleza y condiciones.

Por otro lado, aparte de dichos requisitos de publicidad se establecen dos importantes normas sobre la materia:

En caso de insolvencia provisional o definitiva del socio único o de la sociedad, no serán oponibles a la masa de acreedores aquellos contratos entre el socio único y la sociedad que no cumplan los requisitos de publicidad que acabamos de comentar (o, por lo que se refiere a la memoria, si ésta no ha sido depositada en Registro Mercantil).

Durante el plazo de dos años a contar de la fecha de celebración de cada uno de los contratos entre el socio único y la sociedad, el socio único responderá frente a la sociedad de las ventajas que directa o indirectamente haya obtenido en perjuicio de ésta, como consecuencia de dichos contratos.

Esta nueva reglamentación, por decirlo brevemente, da carta de naturaleza a una figura que tanta controversia ha originado en la doctrina y, por otra parte, tan especialmente apta para dar lugar a lo que genéricamente suele entenderse como «abusos de la persona jurídica».

Con la vigente configuración legal de la sociedad unipersonal se produce, en definitiva, una cierta distorsión del significado tradicionalmente atribuido a la persona jurídica, en la medida en que el Derecho positivo legitima a una sola persona física para utilizar la «vestidura societaria», a todas luces explicable (sin perjuicio de otros objetivos) por el deseo del «socio» de sustraerse a las consecuencias de la responsabilidad patrimonial ilimitada. Dicho de otro modo, el «socio único» busca de forma declarada, no encubierta, el propósito de reducir o limitar la responsabilidad que pueda originar el desarrollo de su actividad económica, eludiendo así la suya personal.

La pregunta que ahora puede suscitarse es la de si esta actual configuración de la sociedad unipersonal ha de producir algún impacto en la eventual puesta en práctica del levantamiento del velo de una sociedad mercantil.

Mi opinión es la de que ahora puede estar más justificada que nunca la indagación o penetración en la interioridad de la sociedad (me refiero a las formalmente pluripersonales), puesto que si la Ley brinda al empre- 
sario la oportunidad de beneficiarse de la «cobertura» constituida por la sociedad unipersonal, parece más reprobable que nunca que el recurso al «artificio» de la persona jurídica se convierta en instrumento para perseguir objetivos distintos de los que le son propios.

B) A continuación menciono algunas sentencias que, o bien rechazan la práctica del levantamiento del velo (en los casos en ellas contemplados, se entiende), o bien se hace advertencia de las cautelas y restricciones que deben adoptarse para la puesta en práctica de ese instrumento judicial.

1. La sentencia de 16 de noviembre de 1993 formula la doctrina de que la aplicación de la doctrina del levantamiento del velo requiere que se pruebe que los entes sociales han sido utilizados para perjudicar los derechos de terceros. El Juzgado de Primera Instancia había estimado la demanda, condenando al demandado al pago de una determinada cantidad. La Audiencia, estimando el recurso de apelación, absolvió al demandado. Interpuesto por la parte actora recurso de casación, el Tribunal Supremo declaró no haber lugar al mismo, siendo ponente el señor Ortega Torres.

En el recurso de casación se argumentaba por el demandante que el demandado había actuado en «fraude de terceros», en cuanto las dos sociedades que representa carecen de toda solvencia y en cierto sentido hasta de personalidad, afirmación que se pretendía demostrar con certificaciones del Registro Mercantil.

El fundamento jurídico tercero de la sentencia se enfrenta con el motivo de casación en que el demandante alegaba la circunstancia de que el demandado era la persona que tenía el control absoluto de las dos sociedades en cuestión. Y a tal efecto el Tribunal Supremo dice:

«En cuanto al segundo apartado del motivo, que versa sobre la alegación de que el señor P. "es sin duda ninguna la persona que tiene el control absoluto de las dos sociedades ... que es el que le permite actuar sobre la base de una representación que en definitiva no es otra cosa sino la posibilidad de evitar que desde el punto de vista personal tenga que soportar las consecuencias del incumplimiento de sus obligaciones", carece también de consistencia, dado que no está probado el hecho de que se parte y, además, aunque fuera cierto, no sería determinante de su responsabilidad por las operaciones realizadas como representante de las sociedades, pues falta prueba de que se escudase en los entes sociales para perjudicar los derechos del señor $R$. de V., que es lo que permitiría, al menos en principio, hacer aplicación de la doctrina jurisprudencial sobre "levantamiento del velo" de persona jurídica.»

2. Sentencia de la Audiencia Provincial de Segovia de 2 de julio de 1992.

Se trataba del recurso de apelación interpuesto por la parte demandante, para que en aplicación de la doctrina del levantamiento del velo de 
la persona jurídica se hiciese extensiva la condena a la entidad mercantil «Colegio I., S.A.» a los socios y administradores de la misma, don Francisco y doña Milagros, que también habían sido demandados.

La Audiencia desestima el recurso de apelación, siendo ponente el señor Conde-Pumpido Tourón.

Esta sentencia refleja las cautelas que deben presidir la aplicación de la técnica que nos ocupa, precisamente porque la figura de la persona jurídica — cuando está utilizada de forma correcta - responde al razonable y legítimo deseo de limitar la responsabilidad patrimonial de los miembros que la componen. Por ello, la sentencia dice:

«Es cierto que la posible utilización de la persona jurídica diferenciada como instrumento de fraude o fuente de abusos ha dado lugar en la doctrina española y mundial ("Durchgriff", en Alemania, "disregard of legal entity", en los países anglosajones), a reacciones que posibilitan en determinados casos penetrar en la interioridad de la persona jurídica, "levantando el velo", como ha hecho nuestro Tribunal Supremo en sentencias como la de 28 de mayo de 1984, 18 de setiembre de 1987, 4 de marzo y 29 de abril de 1988, 7 de febrero, 2 y 13 de marzo de 1989, entre otras, pero sin que dicha doctrina implique, en absoluto, que con carácter general pueda prescindirse del mecanismo de la personalidad jurídica para exigir responsabilidad directa a los socios, pues ello supondría vaciar de contenido una institución legal, prescindiendo del obligado respeto a las disposiciones del legislador, y prescindir de un buen instrumento técnico del Derecho patrimonial que, frente a la posibilidad de abusos, presenta indudables ventajas, acreditadamente demostradas. Por ello no es suficiente aludir a la doctrina del "levantamiento del velo" para reclamar, en cualquier caso, la responsabilidad directa de los socios, sino que se hace necesario que se trate de determinados supuestos, bien cuando el propio legislador ordena prescindir de la cobertura social (artículo $75 \mathrm{o}$ artículo 249 de la Ley de Sociedades Anónimas, por ejemplo), o bien cuando a través de la personificación de la sociedad se intenta cometer un abuso de derecho, o un fraude de ley, en aquellos casos que la jurisprudencia ha ido poniendo de relieve, en los que bien la propia creación de la sociedad tiene por objeto eludir el cumplimiento de un contrato, burlar los derechos de un tercero o eludir la ley, bien se utiliza la personalidad jurídica para encubrir que los socios se dedican a actividades que les están prohibidas, o bien cuando - no como objetivo de su creación, pero sí como resultado - la cobertura formal de la persona jurídica se utiliza con fines defraudatorios.»

En el fundamento jurídico tercero, la sentencia hace aplicación de la doctrina anteriormente mencionada al caso discutido en aquel pleito. La Audiencia parte de la afirmación de que no cabe estimar que nos encontremos ante un caso de abuso de la personalidad jurídica, sino ante un 
funcionamiento normal del sistema de personalidad jurídica diferenciada, que tiene precisamente como objetivo limitar la responsabilidad de los socios frente a terceros que contratan con la sociedad. Y en este sentido, la sentencia advierte:

«En efecto, en el caso actual ni cabe suponer que la sociedad Colegio I., S.A., se constituyó para ser utilizada como cobertura formal con ánimo defraudatorio, ni se ha utilizado, en la práctica, para defraudar la ley o cometer abuso alguno de derecho, ni siquiera se ha ocasionado grave perjuicio a un tercero, pues la entidad demandante contrató con la sociedad Colegio I., S.A., a sabiendas de su condición de arrendataria de las instalaciones, y por otra parte la demandada cumplió el contrato convenido mientras le fue posible, e incluso devolvió la totalidad de la cantidad adeudada, quedando únicamente pendiente el cumplimiento de una cláusula penal (muy rigurosa y muy rigurosamente aplicada por el juzgador de instancia), cuya falta de pago no puede apreciarse como una circunstancia que pueda justificar, en absoluto, el que se prescinda de la personalidad jurídica de la entidad con quien la demandante contrató con pleno conocimiento y sin indicio alguno de fraude o abuso por la parte demandada, ya que si de algún abuso pudiera hablarse en este caso es de la exigencia del cumplimiento de una elevadísima cláusula penal (desproporcionada con los perjuicios reales que pudieran haberse irrogado), dudosamente aplicable al caso, tanto por razones del cumplimiento (forzado) como por su propia redacción y forma de cifrar la indemnización (...) conduce a la conclusión de que estaba prevista para un incumplimiento de la parte contraria.»

3. La sentencia de la Audiencia Provincial de Salamanca de 15 de abril de 1994 declara que la penetración en el sustrato de la persona jurídica es medida excepcional, que ha de aplicarse con toda prudencia. Y se refiere la resolución a los casos en que los Tribunales pueden prescindir de la forma externa de la persona jurídica para hacer llegar la responsabilidad a las personas que la integran.

Una sociedad, acreedora de otra denominada «C. y L., S.L.», había demandado a esta última en reclamación de determinada cantidad. Recayó sentencia firme por la que se condenaba a la sociedad demandada a abonar la suma reclamada. No obstante, intentada la ejecución en vía de apremio no fue posible el cobro, por la situación de insolvencia en que se encontraba la demandada y estar comprometidos sus bienes en favor de otros acreedores con derecho preferente. Así las cosas, la sociedad actora, que lo era también en el pleito que ahora nos ocupa, formuló demanda contra dos personas físicas, administradores únicos de la citada «C. y L., S.L.». Esta última demanda fue desestimada por el Juzgado. Entablado recurso de apelación por la actora, la Audiencia lo desestimó, siendo ponente el señor Amaya Pérez. 
En su fundamento jurídico primero, la sentencia que nos ocupa dice que los antecedentes del caso obligan "a dejar sentado en qué se traduce el levantamiento del velo, su alcance y casos en que puede aplicarse y si el supuesto que nos ocupa recaba, por sus circunstancias, aplicarle dicho tratamiento...».

Sentada esta premisa, la resolución dedica la primera parte del fundamento jurídico segundo a recoger la doctrina jurisprudencial sobre el levantamiento del velo, con mención de los conocidos pronunciamientos de la Sala Primera del Tribunal Supremo al respecto. Se advierte que si esa doctrina «ha adquirido en los últimos años una gran significación en la jurisprudencia de nuestros Tribunales, sin embargo se percibe en ella una tendencia a convertir la técnica del levantamiento del velo, de por sí excepcional, en un instrumento genérico para resolver todos los problemas que no encontrarían solución justa en la aplicación positiva de la Ley».

Pero la resolución insiste en la excepcionalidad de este mecanismo, que, dice, "encuentra su porqué en no poder ser violado ni abolido sin más el derecho a la existencia que tienen las entidades a las que se reconoce personalidad por el ordenamiento jurídico, desde el momento de su constitución legal, en tanto no se den irregularidades que aconsejan hacer uso de tan especial medida».

Por eso, la sentencia señala que «la principal cuestión estriba en saber cuándo los Tribunales pueden prescindir de la forma externa de la personalidad jurídica para, penetrando a través de ella, alcanzar a las personas y bienes que bajo su manto se cobijan; y siendo variados por demás los supuestos a que se viene aplicando tan drástica medida, y que en líneas generales y por vía de ejemplo se concretan en los casos en que no hay independencia de patrimonios, aquellos en que se protege una apariencia de poder de gestión, las de unidad de gestión comercial entre las entidades y las más frecuentes de creación ficticia de la sociedad, cuando ésta no desarrolla ninguna actividad propia e independiente, descubriéndose que carece por completo de consistencia y actuando como testaferro otra persona».

Después de estos pronunciamientos la Audiencia dedica el fundamento jurídico tercero de su sentencia a formular casos más específicamente aptos para llevar a cabo el levantamiento del velo, con aplicación de sus reflexiones teóricas a las circunstancias del que en este pleito se enjuiciaba.

$\mathrm{Y}$ a tal fin dice la sentencia:

«Al no poder ponerse en duda el haberse constituido, en su día, la sociedad que nos ocupa, con observancia de los requisitos establecidos por Ley, para tener personalidad jurídica propia y operar en el ámbito mercantil por medio de sus gestores o administradores con escrituración de la 
misma, e inscripción en el Registro Mercantil, ello sería suficiente para rechazar, de plano, que se esté en presencia de una sociedad ficticia y aparente nacida tan sólo como medio fraudulento para evitar las responsabilidades personales de quienes la constituyeron, lo que mal se viene con su actividad propia - fabricación y venta de ladrillos y materiales de construcción y adquisición, enajenación y venta de solares, terrenos y naves industriales_, conforme consta el artículo 2. ${ }^{\circ}$ de sus Estatutos - y con el capital aportado de diez millones de pesetas - que aunque bajo ya en la fecha de su constitución, ha de valorarse tan sólo como capital de inicio suficiente, cuando en contrapartida las cargas son lógicamente reducidas en sus primeros pasos, máxime cuando no se constata que su trayectoria fuese irregular a través de los años en que vienen desenvolviéndose; de ahí el que partiéndose de una sociedad bien constituida, con personalidad propia, no ficticia, quede por resolver si en su devenir su gestión o administración pudiera estar en el plano de la fraudulencia, con el consiguiente perjuicio para sus acreedores, se produzcan tales irregularidades culposa o dolosamente y como vía para estimar la realidad de una identificación absoluta entre la sociedad y sus socios, que demanda la responsabilización de éstos como se pretende en la acción ejercitada; actuación irregular y fraudulenta que pudiendo darse a través de un doble camino, por un lado mantenimiento de una sociedad en claro estado de insolvencia sin legalizar su situación, y por otro, la descapitalización de la misma, con desplazamiento del capital a sus socios, ello obliga a examinar tal problemática en relación al caso que nos ocupa; y no ofreciendo duda que pese a las extremas circunstancias económicas por que atraviesa, en estos últimos años, no cabe sin embargo partir de una situación de insolvencia, a la que de momento no se ha llegado, máxime cuando la misma sigue operando, aunque con dificultades serias, y por tanto no retirada del tráfico juridíco, no menos claro resulta que la gestión llevada a cabo, a primera vista, se desenvuelve en el terreno de la normalidad, sin que existan razones en los autos para tacharla de irregular y oculta, cuando existiendo una contabilidad y un control impositivo - de lo que es fiel expresión la documental aportada del impuesto de sociedades, obrante a los folios 217 y siguientes, y referente a las distintas anualidades - viene cumpliendo su cometido, en la medida de sus posibilidades, con la celebración de las exigidas Juntas ordinarias, y sin que se aparezca mermado su patrimonio por comprometido que esté, conforme se constata a través de los embargos que pesan sobre sus bienes y la nota de éstos obrante al folio 87; y si de estas consideraciones generales se pasa directamente al principal motivo esgrimido por la sociedad actora apelante para el levantamiento del velo y responsabilización de sus dos administradores, cual es la desviación de los 95 millones por ella pagados a la sociedad «C. y L., S.L.» por la compra de un solar y naves, cantidad que se dice pasó al patrimonio particular de los socios demandados, tampoco encuentra este extremo probanza alguna, cuando es el propio Banco Central Hispano que descontó los efectos cambiarios de la venta el que certifica que 
fueron abonados en la cuenta de la referida sociedad; y si a ello se une el cumplimiento por ésta de aquello a que se comprometió, por documento privado de 24 de junio de 1989, elevado a escritura pública de 30 de noviembre de igual año, concretamente la entrega de la parcela y naves, en justa contrapartida al precio recibido, las deficiencias que en éstas pudieran apreciarse y que motivaron los autos 34/1992 no tendrían la entidad suficiente para, su solo resarcimiento ( $s i c$ en nuestra fuente), fundamentar el actuar fraudulento exigido.»

El fundamento jurídico cuarto insiste en la cautela que debe presidir la aplicación del levantamiento del velo, diciendo que es inviable penetrar en el substrato de la sociedad en función de su apurada situación económica (de la que se advierte que no es inhabitual en los años de recesión económica que están sucediéndose), añadiéndose que por ser una medida excepcional (la del levantamiento del velo), ha de aplicarse con toda prudencia para así respetar el derecho de las sociedades a su existencia y desenvolvimiento, desde que les es reconocida su propia personalidad jurídica.

4. Sentencia de la Audiencia Provincial de Vizcaya de 22 de setiembre de 1993. La Sala denuncia la inadecuada invocación de la idea de «socio único»y declara la improcedencia de la aplicación del levantamiento del velo.

Recayó esta sentencia en un recurso de apelación en que el actor solicitaba la revocación parcial de la resolución recurrida, pidiendo que la condena al pago de una cantidad se hiciera extensiva al demandado J.L., en su calidad de administrador único de la sociedad A.C., que había sido condenada en la instancia. Se invocaba al efecto la teoría del levantamiento del velo jurídico y los principios de responsabilidad del administrador social frente a los acreedores. La sentencia desestima el recurso siendo ponente la señora Cuenca García.

La resolución descarta la práctica del levantamiento del velo de la sociedad del caso, diciendo:

«Mas tal teoría no es aplicable en el caso de autos, ya que no nos encontramos, o al menos el apelante sobre quien pesa la carga de la prueba no ha acreditado que el demandado sea el "dueño de la sociedad", pues no debe confundirse la condición de administrador único con la de socio único mayoritario, y que a juzgar por la copia, no adverada, de la inscripción registral de la sociedad demandada, obrante a los folios 26 y siguientes, el señor A. era titular del 25 por 100 de las acciones emitidas, repartiéndose las restantes entre otros tres socios, de las que M.B. tenía 35 y los demás 20 sin que conste vinculación familiar entre ellos, y sin que le sirva de justificación el hecho de que la actora contratara directamente con la sociedad a través del demandado, pues éste era su administrador 
41 LA DOCTRINA DEL «LEVANTAMIENTO DEL VELO» Y LAS SOCIEDADES INTERPUESTAS 51

con facultades al efecto y sin que pueda entenderse por ello que la deuda era imputable al patrimonio personal del señor A., pues no contrataba para sí, sino para la sociedad, lo que conocían perfectamente los demandantes que giraron las facturas a nombre de la sociedad.» 